\title{
Antitrust, Deregulation, and the Newly Liberated Marketplace
}

\author{
Stephen G. Breyer $\uparrow$
}

Professor Handler's topic for this Article is whether the free market alone can protect the public from potential risks posed by newly deregulated industries. I do not think that Professor Handler, in asking this question, expects to hear yet again the major arguments in favor of or against deregulation. Nor do I think he is asking for a detailed empirical balance sheet of the benefits and costs of deregulation so far. Rather, I take him to be asking an important public policy question: What are the special risks to the public that may arise in deregulated industries, and how might sound public policy alleviate or avert these risks?

This Article analyzes four special risks associated with deregulation by focusing upon two recently deregulated industries-airlines and telecommunications. Part I introduces the classical relationship between antitrust and economic regulation and describes its application to the airline and telecommunications industries. Part II analyzes the difficulties of applying antitrust policy to airline mergers-difficulties that illustrate the risk that general antitrust policy will fail to take account of the special characteristics of individual industries. Part III discusses the risk that government policymakers, in an era of deregulation, will protect competitors instead of protecting competition, thus confusing antitrust's ends with its means. Part IV analyzes the risk that local regulators will not follow sound economic principles when defining the relationship between newly competitive and still-regulated industries. Finally, Part V examines the risk that residual areas of potential monopoly power, often called "bottlenecks," will do anticompetitive harm in newly deregulated industries.

$\dagger$ Judge, U.S. Court of Appeals for the First Circuit, Boston, Massachusetts. A.B. 1959, Stanford University; B.A. 1961, Oxford University; LL.B. 1964, Harvard University. This Article reflects only nonjudicial views and seeks to avoid any conclusions about legal matters. In fact, the author has potential biases, arising out of various connections with the subject matter, and the reader is warned accordingly. 
I

ANTitrust, Regulation, AND the Deregulatory EXPERIENCE

\section{A. The Classical Theory: Antitrust and Economic Regulation}

To understand the risks that deregulation poses, one must understand the classical theoretical relationship between antitrust and economic regulation. In classical theory, both institutions aim to achieve similar economic objectives. One might describe these goals as the "benefits" that can flow from workable competition, namely (1) prices close to incremental costs, leading to buying and production decisions that minimize economic waste, (2) efficient production processes, and (3) innovation as to both product and production process.

Economic regulation bypasses the competitive process and seeks to obtam these benefits directly. Regulation typically involves an administrative body that deals with private firms through an adversarial process. Regulators create a vast network of rules and orders that determine the regulated firms' prices while, in principle, spurring those firms toward innovation and production efficiency.

Antitrust, on the other hand, tries to achieve these benefits indirectly. The antitrust laws set forth a few negatively phrased directives, which are enforced by the courts or the Federal Trade Commission. They prohibit both anticompetitive market behavior, such as price fixing, and behavior that may lead to or help maintain anticompetitive market structures. Sometimes, as in the case of unjustified monopoly, they may require restructuring a market. In essence, they promote competition so that competition itself can bring us its economic benefits. ${ }^{1}$

From a classical perspective, these economic benefits, perhaps like happiness or reputation, are best secured when one does not aim at them directly. Decentralized individual decisions made in a workably competitive marketplace are more likely to prove economically efficient, to bring about efficient production processes, and to encourage desirable innovation than are the centralized, bureaucratic decisions of the economic regulator. Classical theory emphasizes the many systematic institutional features of regulatory systems that prevent them from ever coming close to replicating the effects of well-functioning competitive markets.

The classicist nonetheless finds reasons for regulating. He points to "defects" in certain markets that prevent competition from working

1. I do not mean to suggest that competitive markets will promote efficiency under all circumstances. See Elzinga, The Goals of Antitrust: Other than Competition and Efficiency, What Else Counts?, 125 U. PA. L. REv. 1191, 1191 n.1 (1977) (noting that a competitive market will not secure efficiency in an industry with declining long-run average costs). 
properly. ${ }^{2}$ For example, he may point to the natural monopoly, where economies of scale are so large that a single firm can produce an industry's entire output at lowest cost. He may claim that competitively set prices take inadequate account of "spillover costs," such as environmental pollution. He may express concern about inadequate consumer information or exorbitant rents, which for one reason or another may require direct governmental intervention. For present purposes, it is important to see that regardless of the merits of these reasons in any particular case, the classicist embraces regulation faute de mieux. Competition is more desirable, and antitrust may help maintain competition. Yet for one reason or another, in these special markets, competition cannot work or by itself is inadequate. Thus, one must turn to regulation as a supplement or substitute.

On this view, antitrust is not another form of regulation. Antitrust is an alternative to regulation and, where feasible, a better alternative. ${ }^{3}$ To be more specific, the classicist first looks to the marketplace to protect the consumer; he relies upon the antitrust laws to sustain market competition. He turns to regulation only where free markets policed by antitrust laws will not work-where he finds significant market "defects" that antitrust laws cannot cure. Only then is it worth gearing up the cumbersome, highly imperfect bureaucratic apparatus of classical regulation. Regulation is viewed as a substitute for competition, to be used only as a weapon of last resort-as a heroic cure reserved for a serious disease.

\section{B. The Modern Experience: Airline and Telephone Deregulation}

This view of antitrust and regulation may be inadequate, inaccurate, incomplete, or all three, but it is important to understand because it helps to explain much of the economic deregulation we have seen in the past fifteen years. Airline deregulation, for example, reflects the reformers' belief that airline markets are workably competitive. Even markets with only one or two carriers typically are considered "contestable." If entry by other firms is easy enough to keep carriers serving the market from raising their fares too high, then regulation is unnecessary.

The reformers also argued that the "market defect" that allegedly necessitated airline regulation did not exist. The regulators could not explain what they meant when they raised the spectre of "excessive competition." Antitrust enforcement could prevent "predatory pricing," if that is what they feared. The structure of the airline industry foreclosed any risk of plant closure during a recession, if they were worried about

2. See generally S. BReYer, Regulation and ItS ReForm 15-35 (1982) (reviewing the classical rationales for economic regulation and common criticisms of the rationales).

3. See id. at $156-61$. 
wasteful investment. Even Colonel Gorell, the industry spokesman who appealed for protectionist regulation in 1938, admitted that he had never actually witnessed excessive competition among airlines-though he claimed to "have been shaking in [his] boots" because it had come so close. $^{4}$ If no defect could be demonstrated in the 1930's-after several years experience without economic regulation-then one might question whether it would materialize with deregulation in the 1970's.

The strength of the arguments that the industry could support competition and the weakness of the regulatory justification led reformers to present their claims to Congress. After entertaining extensive debate and considering vast amounts of empirical evidence, including practical regulatory experiments in California and Texas and the initial results of Alfred Kahn's first experiments with deregulation at the Civil Aeronautics Board (CAB), Congress enacted legislation deregulating the industry. 5

Deregulation of the telephone industry was similar, at least in theory. Reformers became convinced that both telephone equipment manufacturing and long distance telecommunications service could become workably competitive industries. They lost confidence that "natural monopoly"-the market defect that allegedly required regulation-in fact existed in these markets. They thought that both the telephone equipment manufacturing industry and the long distance telecommunications service industry were large enough to support not just one, but several, competing firms of efficient size. ${ }^{6}$

Despite their similarities, airline deregulation and telephone deregulation differed in several respects. First, the rationale for telephone regulation ("natural monopoly") was different from that for airline regulation ("excessive competition"). Second, the arguments that long distance telecommunications could not support several competitors were stronger than similar arguments concerning airlines. ${ }^{7}$ Third, there were no practical experiments with long distance telecommunications, as there were

4. Aviation: Hearings on H.R. 5234 and H.R. 4652 Before the House Comm. on Interstate and Foreign Commerce, 75th Cong., 1st Sess. 76 (1937) (statement of Edgar S. Gorrell, President, Air Transport Association of America).

5. Airline Deregulation Act of 1978, Pub. L. No. 95-504, 92 Stat. 1705 (codified in scattered sections of 18, 26 and 49 U.S.C.; the Act is located primarily at 49 U.S.C. $\$ \S 1301-1384$ (1982)).

6. See, e.g., In re Use of the Carterfone Device in Message Toll Tel. Serv., 13 F.C.C.2d 420, 423-24 (1968) (declaring illegal an FCC tariff prohibiting attachment of telephone equipment not provided by AT\&T); J. MEYeR, R. Wilson, M. BAughcum, E. Burton \& L. CaOuetTe, Tile ECONOMICS OF COMPETITION IN THE TELECOMMUNICATIONS INDUSTRY 111-53 (1980) [hereinafter ChARLES RIVER ASSOCIATES] (a Charles River Associates study seriously questioning the existence of natural monopoly in the telecommunications industry).

7. See Sudit, Additive Nonhomogeneous Production Functions in Telecommunications, 4 BELL. J. EcoN. \& MGMT. ScI. 499; (1973) Vinod, Nonhomogeneous Production Functions and Applications to Telecommunications, 3 BELL J. ECON. \& MGMT. SCI. 531 (1972). 
with airlines, that could provide empirical support for the feasibility of competition. ${ }^{8}$ Fourth, the income effects of telecommunications deregulation probably favored the business community, ${ }^{9}$ whereas airline deregulation probably favored the ordmary traveler or consumer. Fifth, Congress found serious problems with the way in which the relevant administrative agency, the $\mathrm{CAB}$, regulated the airlines; ${ }^{10}$ it did not find comparable problems with existing telephone service regulation by the FCC. Finally, Congress was the institution that implemented airline deregulation, whereas the courts and the FCC implemented telephone deregulation. ${ }^{11}$

From the classical perspective, however, the similarities between airline and telephone deregulation are more important than the differences.

8. See Staff of Subcomm. on Admin. Practice and Procedure of the Senate Comm. on the Judiciary, 94th Cong., 1st Sess., Report on Civil Aeronautics Board Practices and Procedures 40-58 (Comm. Print 1975) [hereinafter Kennedy Report].

9. In part, the business community was expected to benefit from the pressure of competition that would reduce or eliminate perceived excess charges that AT\&T had imposed upon long distance, commercial, and urban callers. See infra text accompanying notes 78-81. In addition, businesses, with their more complex needs, would be more likely than most individual consumers to benefit from service innovation.

10. Senator Kennedy's investigation of the CAB revealed that that agency violated relevant regulatory statutes, used inadequate or inproper procedures, inappropriately focused on increasing airline profits rather than reducing fares, followed incoherent route award policies, and skewed its enforcement policies towards stopping charter and other low-fare flights. The investigation produced strong evidence that the Board itself maintained unnecessarily high fares, preventedsometimes unlawfully - new low-fare airlines from entering the industry, and tried to stop service, as well as price, competition. For a detailed account of these policies, see KENNEDY REPORT, supra note 8.

11. The FCC brought about open entry into manufacturing and connecting of telephone equipment. See Proposals for New or Revised Classes of Interstate and Foreign Message Toll Tel. Serv. and Wide Area Tel. Serv., 56 F.C.C.2d 593 (1975) (First Report and Order permitting connection of terminal equipment without carrier-supplied connecting arrangements); 58 F.C.C. $2 \mathrm{~d}$ 736 (1976) (same case) (Second Report and Order extending access to private branch exchanges, key telephone systems, main system telephones, and coin telephones); Carterfone, 13 F.C.C.2d at 423-24 (allowing use of telephone interconnecting devices not furnished by AT\&T).

By contrast, competition did not become legal in long distance switched service until effectively ordered by the District of Columbia Circuit Court of Appeals. See MCI Telecommunications Corp. v. F.C.C., 561 F.2d 365 (D.C. Cir. 1977) (holding that the FCC has no general authority to insist on approval of new services without a finding of "public convenience and necessity"), cert. denied, 434 U.S. 1040 (1978), later proceeding 580 F.2d 590 (D.C. Cir.) (holding that the previous decision's mandate requires AT\&T and the FCC to provide interconnections to $\mathrm{MCI}$ ), cert. denied, 439 U.S. 980 (1978). For an overview of the actions of the FCC and the federal courts from 1959 to 1979, see generally Knieps \& Spiller, Regulating by Partial Deregulation: The Case of Teleeommunications, 35 ADMIN. L. REv. 391, 397-405 (1983).

Finally, the breakup of AT\&T, which was intended to promote competitive conditions in both equipment manufacturing and long distance service, grew out of a consent decree settling judicial litigation. United States v. American Tel. \& Tel. Co., 552 F. Supp. 131, 226-32 (D.D.C. 1982), aff'd sub nom. Maryland v. United States, 460 U.S. 1001 (1983). Under the consent decree (also called the "Modification of Final Judgment" or "MFJ"), AT\&T divested its local service subsidiaries, which now operate independently as regulated local monopolies. AT\&T, in competition with other firms, continues to provide equipment and long distance service. 
These similarities suggest that antitrust can adequately replace regulatory efforts to provide economic protection for the public. They also suggest that the most obvious risk to the public is that the reformers were wrong in thinking that the newly deregulated markets would be structurally competitive.

There are three reasons to resist the temptation to rehearse here the standard arguments about structural competition. First, those arguments have been made many times before. ${ }^{12}$ Second, telephone deregulation is not yet complete, and thus the evidence concerning its advisability is not clear. Since the basic legal changes are in place and are unlikely to be reversed, any discussion of the wisdom of telephone deregulation is likely to prove more academic than useful.

Third, in the airline industry, the evidence so far suggests that the reformers were right: Competition has yielded benefits to consumers. Many new firms have entered the industry, ${ }^{13}$ and more markets are being served by competing airlines. ${ }^{14}$ Since 1974 , the year before the CAB abandoned classical rate regulation and began to let new firms enter the industry, average real fares have fallen twenty-five percent. ${ }^{15}$ Had real fares stayed constant since 1973, travelers would have had to pay $\$ 9.7$ billion more to fly the 270 billion passenger miles they flew in $1985 .^{16}$ Overall, seat availability, flight frequency, and mileage flown have increased. ${ }^{17}$ Employment and certain real wages in the airline industry rose through 1983, though more recently real wages trends may have changed. ${ }^{18}$ Admittedly, comfort and service quality have declined, but

12. See, e.g., S. BREYER, supra note 2, at 292-93 (discussing the debate over natural monopoly and structural competition in the telecommunications industry). For arguments predating deregulation, see KENNEDY REPORT, supra note 8, at 38-40; CHARLES RIVER Associates, supra note 6, at 111-53; G. Douglas \& J. MILleR, ECONOMIC REgulation of Domestic AIR Transport: Theory and Policy (1974); 2 A. KaHn, The Economics of Regulation: PRINCIPLES AND INSTITUTIONS 113-250 (1971).

13. The number of certificated carriers increased from 33 in 1976 to 114 in 1984. See U.S. GENERAL ACCOUNTING OFFICE, DEREgulation: INCREASED COMPETITION IS MAKING AIRLINES MORE EFFICIENT AND RESPONSIVE TO ConsUMERS 12 (1985) [hereinafter GAO REPORT]; Moore, U.S. Airline Deregulation: Its Effects on Passengers, Capital, and Labor, 29 J. L. \& ECON. 1, 5 (1986).

14. See GAO REPORT, supra note 13 , at $15-16$. In the first quarter of $1984,97 \%$ of passengers traveled in markets served by more than three airlines. Id. at 16.

15. See infra Table 1 in Appendix.

16. See infra Table 2 in Appendix. Dollar figures have been adjusted to 1984 dollars using the Consumer Price Index. These figures were calculated on the basis of Department of Transportation Air Carrier Traffic Statistics. See also Bailey, Price and Productivity Change Following Deregulation: The US Experience, 96 ECON. J. 1, 5 (1986) (providing an index of airline fares in 1983 as a percent of the CAB formula fare).

17. GAO REPORT, supra note 13 , at 74 .

18. Although total employment increased overall roughly $9 \%$ between 1976 and 1982 , it has been dropping since 1980. See Moore, supra note 13, at 25-26. Real airline wages were $1.8 \%$ higher in 1983 than in 1977. See S. Morrison \& C. Winston, THE Economic EFFEcTs of AiRLiNe Deregulation 44 (1986). The apparent stability of the figure, liowever, conceals the fact that 
the more crowded conditions and reduced amenities in large part reflect the buying public's preference for lower prices. ${ }^{19}$ Competition has forced a better match between supply and demand, leading to greater efficiency and increased satisfaction of consumer preferences. ${ }^{20}$

At the same time, there is little reason to believe that these benefits have been achieved at the cost of airline safety. Airlines have not been deregulated with respect to safety. Critics correctly point out that the number of airline fatalities in 1985-about 2,000 - was unusually large. ${ }^{21}$ For the most part, liowever, the deaths occurred in crashes of chartered aircraft, whose fares have never been regulated, and foreign carriers. ${ }^{22}$ The single major accident involving a newly deregulated carrier was the "downdraft" crasli of a Delta L-1011 in New Orleans, which resulted in 134 fatalities - only seven percent of the death total for 1985 . Overall, statistics kept since the advent of complete deregulation in 1978 suggest that the airline safety record has improved. ${ }^{23}$

This Article does not focus on the overall merits of deregnlation, but accepts the proposition that deregulation was well conceived in the first place. The classical view would now look to traditional antitrust policy to protect the public. But this view overlooks some important concerns. There are certain special risks and policy problems that arise in these newly deregulated industries. Parts II though V identify and analyze four of them.

II

Risk ONe: General ANtitrust Policy Will Overlook the SPecial Features of PARTICULAR INDUSTRIES

\section{A. Antitrust Policy and Airline Mergers}

Broadly stated, the first of these special risks is that general antitrust policy will not take account of the special characteristics of deregulated industries. This abstract concern is made sensible with a contemporary example: the risk that antitrust policy will fail to deal appropriately or adequately with airline mergers. Antitrust policy may prove too lenient

layoffs of lower paid workers artificially increased the average wage. Id. at 43-44. Recent trendssuch as the increase in nonunion airlines, bargaining agreements calling for wage concessions, and the successful institution of two-tiered wage structures-suggest that deregulation may adversely affect the wage rates of higher paid, unionized employees in the long run. See id. at 44 .

19. See Moore, supra note 13, at 11-14, 26.

20. See GAO REPORT, supra note 13, at 50-52; S. MORRISON \& C. Winston, supra note 18, at 13-42; Bailey, supra note 16 , at 14.

21. See Greenwald, Is There Cause for Fear of Flying?, TIME, Jan. 13, 1986, at 49.

22. Id. (reporting 520 fatalities on Air Japan, 329 on Air India, and 248 on a military charter).

23. See M. Brenner, J. LeEt \& E. Schott, AlrLine Deregulation 128 (1985); Robson, Flying Deregulated Skies is No Greater Hazard, Wall St. J., Jan. 24, 1986, at 20, col. 4. 
on the airlines, allowing mergers that unnecessarily concentrate the industry, thereby reducing competition to the point where fares unnecessarily increase. Alternatively, it may prove too strict, failing adequately to recognize potential gains in efficiency that would lead to savings that competition would pass on to the public.

One might initially ask why this is a special problem for airline deregnlation. After all, the antitrust laws apply to nearly every industry. The risk of an inappropriately lenient, harsh, or indiscriminate antimerger law is always present. Moreover, it is not clear that airline mergers warrant special concern. Proponents of deregulation did not rest their case on likely deconcentration. They argued instead that competition, including potential competition, would force prices down and increase traveler choice, irrespective of whether the industry became more, or less, concentrated. ${ }^{24}$ Given the static market shares and artificial price and service patterns that thirty-eight years of regulation created, ${ }^{25}$ it is hardly surprising that sudden freedom to compete produced radical changes in market shares, leading to some bankruptcies and cost pressures to merge. Finally, despite the many recent mergers and merger proposals, the airline industry is no more concentrated today than it was under regulation, and it will be only marginally more concentrated even if all the currently proposed mergers are approved. ${ }^{26}$ With respect to merger policy, then, airlines would appear on the surface to be no different from other industries.

Airline mergers do warrant unusual scrutiny, however, because empirical generalizations that support current merger policy do not necessarily reflect the special circumstances of the deregulated carriers. By administrative necessity, merger policy deals with typical relations between market structure and competitive behavior. Antitrust rules designed to deal with industry in general may not reflect properly the special features of the airline industry. Some of these features recommend a more stringent policy; others counsel us toward a more lenient one.

24. See KENNEDY REPORT, supra note 8, at 62.63 \& n.128 (referring to testimony of Professor William Jordan that without regulation there would be several hundred competing carriers and to contrary testimony suggesting there could be as few as five).

25. See id. at $96-99,112-30$.

26. As of September 1986, even if all the proposed mergers were approved, the top eight firms' collective market share would be no larger than it was in 1974-approximately $90 \%$ of revenue passenger miles. Based on Department of Transportation traffic data for 1974 and the first two quarters of 1986, the Herfindahl-Hirschman Index (HHI) has increased only slightly, from 1272.9 to 1339.6 (calculations on file with the author). 


\section{B. The Argument for a More Stringent Airline Merger Policy}

Four factors contribute to the argument that present antitrust policy will not prove sufficiently strict in dealing with proposed airline mergers.

\section{Recent Changes in Antitrust Enforcement Policy}

Although the antitrust community lias focused considerable attention upon changes in both the method for calculating market concentration and the substantive standards that define levels of concentration that the Department of Justice will tolerate, ${ }^{27}$ the change in the Department's attitude toward the role of potential competition is, for present purposes, more significant. ${ }^{28}$ One can understand this change in attitude by focusing upon two hypothetical mergers.

First, imagine a proposed merger of two firms, each with a fifteenpercent share of a market presently consisting of six large firms and ten small ones. A merger optimist, realizing that market share figures reflect only rough generalizations drawn from behavior in many different industries, will look for other indicators of likely future industry behavior. If there are three potential competitors that might enter the market should prices rise, he will hesitate to condemn the merger. He sees the presence of potential competitors as a safety valve, available to keep anticompetitive behavior, such as tacit price collusion, under control.

The merger pessimist, however, will not shade the market figures of the two merging firms to reflect the presence of potential competitors on the edge of the market. In her view, "potential competition is no substitute for actual competition." Of course, she admits that in extreme cases this generalization fails. For example, in the 1960's, the Department of Justice thought it might have found an envelope paper monopolist in a single firm that accounted for $100 \%$ of the envelope paper business. Many firns not then producing envelope paper could have started doing so quite easily, however, simply by turning a dial on their machines to change the paper's thickness. Where entry barriers are so low that a "monopolist" has no power to raise prices, even the pessimist will not

27. Compare Calkins, The New Merger Guidelines and the Herfindahl-Hirschman Index, 71 CALIF. L. REv. 402 (1983) (discussing the implications of replacing the concentration ratio with the HHI as a measure of market concentration) with Baker \& Blumenthal, The 1982 Guidelines and Preexisting Law, 71 CALIF. L. REv. 311, 334 \& n.87 (1983) (arguing that the switch in measures of market concentration is unlikely to affect the outcome of cases). See also Kauper, The 1982 Horizontal Merger Guidelines: Of Collusion, Efficiency, and Failure, 71 CALIF. L. REV. 497, 510 \& n.30 (1983) (discussing the increased levels of concentration tolerated by the Justice Department in 1982 as opposed to 1968).

28. Compare Merger Guidelines of the Department of Justice-1968, 2 TRADE REG. REP. (CCH) If 4510 (Aug. 9, 1982), with Merger Guidelines of the Department of Justice-1982, 47 Fed. Reg. 28,493 (1982). The 1982 Merger Guidelines expressly discuss potential competition only in the context of nonhorizontal mergers. See id. at 28,499-500. 
worry about proposed mergers. In the ordinary case, however, the pessimist will hesitate to discount the loss of actual competition. She knows that mergers within a market increase the risk that firms will raise prices from competitive levels up to the height of the entry barrier, up to the point where potential competitors will step in.

Now imagine that instead of the proposed merger of actual competitors in the aforementioned market, two of the three potential competitors propose to merge. The optimist will not worry very much about this potential merger either. He will note that after the merger, two potential competitors will still remain, and the market will continue to support many actually competing firms. He will defend the merger by arguing that as long as actual competition exists, potential competition will not be an important force for keeping prices low.

The pessimist also has a different attitude towards this proposed merger. She fears the removal of even a potential competitor, for she suspects that the potential competitor's threat of entry may have had a present, perhaps unmeasurable, effect in keeping prices low. The pessimist fears that the elimination of a potential competitor will increase the probability of anticompetitive behavior.

The recent change in attitude regarding antitrust enforcement can only be described as a shift from the views of the pessimist to those of the optimist. The enforcers believe they have scientific support for such a shift because many economists argue that antitrust merger policy in the 1960 's was too stringent. ${ }^{29}$ Critics respond that the enforcers are overreacting by using more lenient concentration numbers, shading those numbers to reflect potential competitors, and treating less seriously horizontal mergers that remove potential competitors. They are double- or triple-counting-or non-counting-the number of competitors or potential competitors. The resolution of the argument depends upon matters that are notoriously difficult to determine empirically, such as the height of entry barriers and the tendency of firms to raise prices when faced with potential competitors. Here we need note only the change in enforcement attitude.

\section{The Importance of Potential Competition in the Airline Industry}

Advocates of deregulation did not argue that each airline would find itself battling hosts of actual competitors. They claimed only that the threat of entry into a particular inarket by airlines not currently serving that market would hold prices down. ${ }^{30}$ The relevant market for the trav-

29. See, e.g., Y. Brozen, Concentration, Mergers, and Public Policy 12-14 (1982) (arguing that antitrust enforcers' focus on concentration is misguided).

30. See, e.g., Oversight of Civil Aeronautics Board Practices and Procedures: Hearings Before the Subcomm. on Admin. Practice and Procedure of the Senate Comm. on the Judiciary, 94th Cong., 1st 
eler is usually a "city pair," the two cities between which the traveler wishes to fly. ${ }^{31}$ The extent to which a threat of entry into this market can hold down prices is a matter of degree. An airline that serves City $A$ and City $B$, but does not fly between them, can enter the $A-B$ market at very low cost, and there are several such airlines serving most major routes. ${ }^{32}$ For carriers that serve only one end point, $A$ or $B$, the cost of entering the $A-B$ market is higher. For airlines in the general region, but not serving either $A$ or $B$, the cost is higher still. Entry costs rise continually as one considers competition from firms elsewhere in the nation, charter carriers, firms with extra planes elsewhere in the world, and firms that would enter the industry from scratch. Congress, as early as 1975, believed that there were enough potential entrants at the low end of the entry cost continuum to keep prices low in particular markets. ${ }^{33}$

One cannot easily determine the "correct" number of potential entrants necessary to keep prices close to competitive levels. One can only say qualitatively that the nearer the potential competitor and the easier it is to enter a particular city pair, the greater the threat of entry and the closer to the competitive level prices are likely to be. Given the importance of potential competition, every unnecessary removal of a significant carrier as an independent entry-threatening entity gratuitously raises the probability of unwarranted price increases.

\section{The Political Significance of Airline Deregulation}

Airline deregulation is a great experiment in the power of the free market to help the consumer. Yet, it needs friends. Business travelers, who are less sensitive to price than other travelers, dislike crowded planes and airports. Unions are understandably unhappy about wage cuts and freezes. Towns that have lost service are keenly aware of their losses. ${ }^{34}$ Under these circumstances, savings in economic efficiency must

Sess. 672 (1975) (statement of William Kutzke, Office of General Counsel, Department of Transportation).

31. Market definition may be contested in merger cases. For example, in hearings concerning the merger of Northwest and Republic Airlines, the Department of Justice advocated adoption of a product market definition of non-stop flights between city pairs. Republic countered that the Department's definition was too narrow because it excluded substitute services that might be offered by connecting or one-stop flights. Similarly, in Department of Transportation hearings regarding the merger of Texas Air and Eastern Airlines, witnesses debated whether the appropriate market definition ought to be airport pairs, city pairs, or the complex of services representative of a hub and spoke network.

32. In the early 1970 's, two or more airlines not actually serving a city pair served both endpoints of every major route segment. See KENNEDY REPORT, supra note 8, at 63.

33. See id. at 9.

34. Only one small city lost service altogether between 1976 and 1983 , but over $40 \%$ of smaller cities lost some service. See Moore, supra note 13, at 6, 15. But see GAO REPORT, supra note 13, at 29 (reporting that 114 nonhub communities wholly lost scheduled air service between 1978 and 1984). Professor Kahn reports that the only communities that have lost scheduled service to date 
be translated into lower prices. The ordinary traveler must understand that fares are significantly lower, or deregulation will lose effective political support.

\section{The Department of Transportation's Authority Over Airline Mergers}

In 1984, amendments to the Airline Deregulation Act transferred responsibility for determining the legality of a proposed merger to the Department of Transportation. ${ }^{35}$ Given its institutional history, however, that department may be less sensitive than the Department of Justice to potential anticompetitive problems. The Department of Transportation's relative inexperience in enforcing antitrust law suggests that it should scrutinize with special care the airline mergers opposed by the Antitrust Division.

\section{The Argument for a More Lenient Airline Merger Policy}

The primary reason for fearing that ordinary antimerger policy will prove too strict derives from the fact that antimerger enforcers rarely confront industries that are emerging from nearly forty years of regulation. The enforcers must bear in mind that the $C A B$ artificially stabilized airline market structure. Between 1938 and 1972, for example, the airline industry grew by $23,800 \%$, but the market shares of the major carriers changed very little. ${ }^{36}$ The leading carrier, United, accounted for just over twenty percent of industry sales in 1938 and roughly the same in the early 1970's. ${ }^{37}$ The market share of the four largest firms fell from more than eighty percent in 1938 to roughly sixty percent in 1972, but the $\mathrm{CAB}$ permitted no significant new firm to enter the industry. ${ }^{38}$ The $C A B$ also carefully controlled the airlines' routes and services. The industry's route structure reflected to a considerable degree the CAB's "handicapping" system of awarding more profitable, less competitive routes to weaker carriers. The fare structure reflected neither costs nor traveler demand so much as a bureaucratic rule of "equal fares for equal miles." 39

Deregulation of the airlines has upset these longstanding patterns of operation. Free competition has meant experimentation with fares and service. It has meant radical change as firms discover that they must

are those that were previously served by noncertificated carriers. This is likely due to the fact that the Deregulation Act itself provided for subsidies to insure that no community enjoying certificated service would lose it within the first ten years of deregulation. Kahn, American Deregulation Lessons for Europe, Wall St. J., Oct. 2, 1986, at 6, col. 2 (European edition).

35. See Civil Aeronautics Board Sunset Act of 1984, Pub. L. No. 99-443, 98 Stat. 1703 (codified as amended at 49 U.S.C. $\S 1551(b)(1)(C)$ (Supp. 1986)).

36. See KENNEDY REPORT, supra note 8 , at 80.

37. See id.

38. See id. at 79-80.

39. See id. at 118-20. 
respond to cost and demand. It has meant potential failures as firms guess wrong or become the victims of competitive circumstances beyond their control. ${ }^{40}$ These changes create pressures to merge, for merger offers a way to help employees, customers, and owners avoid the ill effects of bankruptcy. Merger also allows the acquiring firm to obtain airplanes or other resources that it may use more efficiently. It may turn out, for example, that Carrier $A$ can use Carrier $B$ 's physical plant or other resources more effectively- $B$ 's fleet may consist of aircraft ideal for $A$ 's operation. Taken together, these considerations mean a lengthy period of industry "shakedown." Antitrust enforcers should take these circumstances into account.

In my view, these facts suggest a need for leniency with respect to "failing company" and "efficiency" defenses in merger cases. Antitrust policy usually insists on fairly clear proof of imminent bankruptcy before accepting a "faihing company" defense to an otherwise unlawful merger. It has also long viewed with suspicion claims that a merger is justified by "efficiency." 41 Greater willingness to accept these defenses inay be warranted in the airline industry because of the greater likeliliood that sucli claims will be well founded in the facts and important to the success of deregulation.

\section{Resolution: Outlines for a Procompetitive Airline Merger Policy}

These two sets of considerations-one arguing for a more stringent merger policy and the other for greater leniency-are not inconsistent. They suggest a policy that-compared to present attitudes-is inore hostile to and suspicious about likely anticompetitive consequences, particularly the loss of potential competitors. But they also suggest a policy that is more receptive to possible justifications for approving an acquisition, sucl as efficiency and imminent failure. Antitrust enforcers would look for the most procompetitive ways to achieve the benefits asserted in these defenses. For example, antitrust enforcers would allow Carrier $A$ to acquire failing Carrier $B$ only if there were no "alternative purchaser" whose acquisition of $B$ would risk fewer anticoinpetitive consequences. ${ }^{42}$ Further, they would insist that acquisitions be structured so as to maximize their procompetitive inpact. This would require airlines to divest themselves of routes in direct competition with those of the companies they propose to acquire. ${ }^{43}$ Enforcement efforts that are sensitive to these

40. Not once did the $\mathrm{CAB}$ allow a carrier to go bankrupt. Id. at 80 . Circumstances are different today. See In re Frontier Airlines, Inc., 74 Bankr. 973 (D. Colo. 1987).

41. See generally 4 P. AREedA \& D. TuRner, ANTITRUst LAW III 939-962 (1980) (discussing the various "economies" defenses).

42. Cf. id. II 927-931 (arguing that proof of no "preferred purchaser" should be required only in cases where the possibilities of harm are substantial).

43. Texas Air's recent merger with Eastern Airlines was conditioned in this manner. Professor 
concerns may resolve some of the apparent tensions in antitrust policy regarding airline mergers. And I suspect that overall they would prove more hostile to airline mergers than are present efforts.

My object here is not to offer specific recommendations, however, but only to highlight the risk that merger policy will not pay adequate attention to the special circumstances of the airline industry. Those circumstances recommend what some might see as a shift away from present antitrust attitudes. Legal authority for any such shift can be found in the statute governing the Department of Transportation, which establishes a "public interest" test to be applied in merger approval decisions. ${ }^{44}$ Since economists continue to believe that the airline industry is not, structurally speaking, a "natural monopoly" or even a "natural tight oligopoly," competition in a free market policed by a strong antimerger policy should provide sufficient protection for the public.

\section{III}

\section{Risk Two: ANTitrust Policy Will Protect COMPETITORS TO THE DETRIMENT OF COMPETITION}

A second special policy risk of deregulation is that government policymakers will protect competitors instead of protecting competition. This is a problem familiar to students of antitrust. ${ }^{45}$ It arises when regulators or antitrust enforcers confuse means with ends by thinking that the object of the law is to protect individual firms from business risks rather than to bring consumers the price and production benefits that typically arise from the competitive process. Where deregulation is at issue, the consequence of misdirecting protection is to threaten to deprive the consumer of the very benefits deregulation seeks.

\section{A. The Experience with Telecommunications}

The most obvious "deregulatory" example of this risk arises in telecommunications. In order to come to the point where the problem is obvious, one must understand a set of complex changes in both the economic perceptions and the legal structure of the industry.

Kahn has argued that United should have been allowed to acquire Pan-American's trans-Pacific routes and assets to preserve three competing American carriers. See Hearings Before the Subcomm. on Monopolies and Commercial Law of the House Comm. on the Judiciary, 99th Cong., 1st Sess., (Feb. 26, 1985) (prepared statement of Alfred Kahn, professor of political economy, Cornell University).

44. See 49 U.S.C. $\S 1378($ b)(1) (Supp. 1986) (even a proposed merger that will substantially reduce competition may be approved if there is no "less anticompetitive" alternative and if the anticompetitive effects are "outweighed in the public interest.").

45. See, e.g., Brown Shoe Co. v. United States, 370 U.S. 294, 344 (1962) ("It is competition, not competitors, which the [Clayton] Act protects."). 


\section{Changing Economic Perceptions}

Ten or fifteen years ago, most economists would have thought the following analogy described long distance service. ${ }^{46}$ Imagine a river spanned by a bridge that costs $\$ 50$ million per year to maintain. The bridge, a natural monopoly, is regulated. A classical problem in regulation is what price the regulator should charge for crossing the bridge. Imagine that a $50 \$$ toll is sufficient to raise the money necessary for maintenance, but a $\$ 1.50$ toll would be needed to raise maintenance money and also provide a fair return to investors. Principles of regulation would seem to require the latter toll. Unless imvestors earn a fair return, their investment has been confiscated, and as a practical matter, future investors probably would not be so foolish as to provide money for projects in regulated industries. ${ }^{47}$

Yet the $\$ 1.50$ toll can have unfortunate consequences. Imagine a person who wants to cross the bridge, who would pay $\$ 1.00$ for the trip, but who cannot afford $\$ 1.50$. The result is a sad one, for the economy could provide this person with what he wants-a bridge crossing - at far less than what he is willing to pay, at a cost of no more than $50 \$$ worth of real resources. But because the toll is $\$ 1.50$, he must remain on the river bank without crossing. Still worse, a ferryboat might offer to take him and others across the river for $\$ 1.00$. If this $\$ 1.00$ fare represents the real resources used in running the ferryboat, the result is very wasteful. Society will have used up $\$ 1.00$ worth of resources to provide by ferry boat what it could have provided by the bridge for only $50 \$$. An extra $50 \$$ of resources has been used unnecessarily.

There are two classical regulatory solutions to this problem. If the regulator is certain that the incremental cost of providing crossings by bridge is less than by ferry, he might simply forbid the ferryboat to enter the crossings market. Suppose, however, that the regulator cannot reliably determine the ferry's incremental costs; these costs may be $\$ 1.00$, but may be only 404 . In that case, the solution may be to allow the bridge to cut its prices to the level of its incremental costs, particularly if the bridge can do so selectively, by charging a lower price to those most likely otherwise to use ferryboats. As a practical matter, the bridge might lower

46. See 2 A. Kahn, The Economics of Regulation 127-52 (1971). Different versions of this analogy, in other contexts, appear in DuPuit, On the Measurement of the Utility of Public Works, 8 AnNales Des Ponts Et Chaussées (2d Ser.) (1844), reprinted in 2 International ECONOMIC PAPERS 83 (1952); Hotelling, The General Welfare in Relation to Problems of Taxation and of Railway and Utility Rates, 6 ECONOMETRICA 242 (1938).

47. See, e.g., Federal Power Comm'n v. Hope Natural Gas Co., 320 U.S. 591, 603 (1944) (requiring a "balancing of the investor and the consumer interests" in fixing utility rates); Missouri ex rel. Southwestern Bell Tel. Co. v. Public Serv. Comm'n, 262 U.S. 276, 289-312 (1923) (Brandeis, J., concurring) (arguing that utility base rates should allow current income to cover all costs, including capital charges, in order to give investors a stable rate of return). 
its tolls for pedestrians, charge a lower toll per person for those who cross as bus passengers, or charge a higher toll for trucks, which cannot use the ferryboat. Though persons discriminated against may complain, the regulator will reply that, in the absence of discrimination, the low-toll bridge-crossers would desert the bridge for the ferryboat. They would then contribute nothing toward covering the fixed investment costs of the bridge. And since fewer bridge crossers would now have to cover the same fixed costs, the price of a crossing would rise still higher. As long as the low-toll crossers are covering at least a portion of fixed costs (by paying a toll of at least 51\$), the discriminatory pricing system-a form of what is called Ramsey pricing ${ }^{48}$ - benefits everyone.

This famous bridge example was thought to have described the AT\&T longlines circumstance before 1975. AT\&T was the bridge. It had a large investment sunk into the provision of long distance service; ${ }^{49}$ its incremental (or marginal) costs of providing that service were lower than its total average costs. The new entrants, such as MCI, were ferryboats that offered customers lower prices. ${ }^{50}$ AT\&T might claim that they did so only because they did not have to recover the costs of the sunk investment; they were $\$ 1.00$ ferry boats. MCI might claim, however, that it was simply more efficient than AT\&T; it was a 40\$ ferryboat. Thus, it should be allowed to compete. ${ }^{51}$

This argument has shifted considerably in the last decade. Because many of AT\&T's sunk costs have been recovered through depreciation, commentators seldom argue that AT\&T's unrecovered depreciation represents a major reason for charging prices higher than those of its long distance competitors. Also, there is now considerable agreement that longlines telecommunications does not possess the characteristics of a natural monopoly. Natural monopoly rests upon substantial economies of scale. According to recent cost breakdowns, however, sixty percent of the present costs of long distance telecommunications represent "access

48. See Ramsey, $A$ Contribution to the Theory of Taxation, 37 Econ. J. 47 (1927).

49. Specifically, the high fixed cost of heavy-duty cable was believed to account for a large portion of AT\&T's revenue requirements. See Note, Recent Federal Actions Concerning Long Distance Telecommunications: A Survey of Issues Affecting the Microwave Specialized Common Carrier Industry, 43 GEo. WASH. L. REv. 878, 894 (1975); see also General Tel. Co., 17 F.C.C.2d 654,657 (1969) (stating that users must bear the "massive capital investments" required to construct and maintain communications routes).

50. By using microwave technology, the competitors avoided AT\&T's high capital costs. See Note, supra note 49, at 894; see also Establishment of Policies and Procedures for Consideration of Application to Provide Specialized Common Carrier Services, 29 F.C.C.2d 870, 925-26 (1971) (First Report and Order) (noting that the proposed plant investments and revenue requirements of the new market entrants were not anywhere near those of AT\&T).

51. See generally Irwin, The Communication Industry and the Policy of Competition, 14 BUfFAlo L. REV. 256 (1964); Waverman, The Regulation of Intercity Telecommunications, in Promoting Competition in Regulated Markets 201 (A. Phillips ed. 1975); Note, supra note 49 , at $894-96$. 
costs"-payments that long distance companies make to local telephone companies to use their lines in order to reach local customers who make or receive long distance calls. Thirty percent represent marketing costs. And only ten percent represent the cost of the physical long distance plant-the portion of costs that can most plausibly be argued to exhibit economies of scale. ${ }^{52}$ Moreover, MCI, Sprint, and other companies have invested nearly as much money in fiberoptic communications equipment and other forms of transmission equipment as has AT\&T, suggesting that they do not believe themselves beset by insurmountable handicaps of scale. ${ }^{53}$ All in all, there is considerable empirical evidence suggesting that AT\&T probably enjoys no significant cost advantage in supplying service. Thus, there is no bridge; all the companies are ferry boats.

\section{Changing Industry Structures}

In part as a result of changed perceptions of the long distance market, two separate but related legal developments have radically changed the structure of the industry. First, the entry of MCI and other carriers into the industry-an entry brought about not by Congress but by the FCC and the courts ${ }^{54}$-made it possible for customers to avoid higher priced AT\&T service and choose lower priced alternatives. The ready availability of these alternatives, facilitated considerably by technological advances, ${ }^{55}$ forced the regulators to allow AT\&T to reduce its prices to some degree, ${ }^{56}$ irrespective of any structural change in the AT\&T system. Moreover, new technology allowed large long distance customers to build their own long distance systems and to bypass AT\&T. ${ }^{57}$ Thus,

52. This cost breakdown appears in Long-Run Regulation of AT\&T's Basic Domestic Interstate Services, F.C.C. No. 83-1147, at 5 (1983) (comments of United Telecom Communications). More recently, AT\&T has similarly broken down its own costs as $60 \%$ access, $25 \%$ general and marketing, $13 \%$ network, and $2 \%$ operator services. NATIONAL TELECOMMUNICATIONS \& INFORMATION ADMINISTRATION (NTIA), U.S. DEP'T OF COMMERCE, NTIA SPECIAl PUb. No. 85-16, ISSUES In DOMESTIC TElecommunications: DiRections for National Policy 91 (July 1985) [hereinafter NTIA]. See generally id. at $91-94$ (describing the costs that long distance competitors face).

53. See Consumer Protection and Finance: Hearings Before the Subcomm. on Telecommunications, Consumer Protection, and Finance of the House Comm. on Energy and Commerce, 99th Cong., 2d Sess., app. at 9, 13 (1986) [hereinafter Consumer Protection Hearings] (statement of Alfred Partoll, Vice President, AT\&T); Reply Comments of AT\&T, supra note 52, at 28-31.

54. See supra note 11.

55. See generally NTIA, supra note 52, at 7-29 (discussing innovations in telecommunications technology).

56. See Investigation of Access and Divestiture Related Tariffs, 97 F.C.C.2d 1082 (1984); MTS and WATS Market Structure, 93 F.C.C.2d 241 (1983).

57. Businesses that primarily call one or a few locations have, in fact, been able to satisfy a large portion of their needs through private systems for some time. See Allocation of Frequencies Above 890 Mc., 27 F.C.C. 359 (1959). More recently, technological advances have broadened the extent of service that private systems can feasibly provide. Merrill Lynch, for example, has 
even if MCI had not entered the long distance market, this threat of bypass would have forced regulators to permit AT\&T to lower its prices.

The AT\&T consent decree ${ }^{58}$ complemented the changes brought about by new entry, separating those portions of AT\&T that, at least arguably, constitute part of competitively structured industries (manufacturing and long distance communication) from those portions of the industry that remained natural monopolies (local operations). The Bell Operating Companies (BOC's), which operate local service, remain regulated by local utility commissions. The object of the decree is to produce a "level playing field" for competition between AT\&T and other carriers and manufacturers in the competitive sections of the industry. ${ }^{59}$

"Deregulation" of the "telephone industry" thus involves two separate industries: manufacturing and long distance service. The consent decree involved both of these industries, splitting both manufacturing and long distance service from local service. Long distance service deregulation involves two sets of governmental actions-one "regulatory set" allowing new firms to compete, and one "antitrust set" (the consent decree) splitting local from long distance service. And there are two separate justifications for these actions with respect to longline service. One justification views $A T \& T$ as the bridge, and $\mathrm{MCI}$ as a potentially lowerincremental-cost ferry boat; the other, more current justification regards all long distance carriers, including AT\&T, as ferryboats. Finally, it is notable that new technology, with its bypass problem, effectively compelled many of the FCC's deregulatory actions entirely independent of the consent decree.

\section{B. The Trouble with Competitive Handicapping}

With all this background in mind, one can understand the major policy risk presently inherent in long distance deregulation. That risk is that AT\&T will not be allowed to compete effectively by cutting its prices. Either the regulatory systein or the antitrust laws may be used to protect new competitors rather than to serve the ends of competition. Indeed, the FCC has thus far acted as a regulatory "handicapper" in three ways.

First, it requires AT\&T to pay far more money to local telephone companies for the right to use local networks to connect with long distance customers (the access charge) than it requires AT\&T's competitors

constructed a facility to provide long distance service to the entire New York financial district. MacAvoy \& Robinson, Winning by Losing: The AT\&T Settlement and Its Impact on Telecommunications, 1 YALE J. ON REG. 1, 37 n.149 (1983).

58. United States v. AT\&T, 552 F. Supp. 131, 226-32 (D.D.C. 1982).

59. See id. at $165-68,171-73$. 
to pay for the same service. ${ }^{60}$ It does so, arguably, because the connection that AT\&T typically obtains is more desirable to consumers (to reach AT\&T longlines the customer need dial only 1 ; to reach other companies, the customer must dial four figures). In the short run, this differential access charge is economically inefficient. ${ }^{61}$ The public is generally best served if it is allowed to select its most preferred option at actual cost. There is no more reason, in the short run, to prevent AT\&T from taking advantage of its better connections than to handicap a bridge because the road connecting it to town is better than the road from town to the ferry. But one can argue that in the long run the public will benefit if AT\&T's superior access to local exchanges-an artifact of its past control over local service-is eliminated. The consent decree has therefore required the local telephone companies to provide equally good connections to AT\&T's competitors by converting their equipment so that customers can choose which longlines firm to connect with $1+$ dialing. ${ }^{62}$ In the meantime, the differential access charge will protect the new companies from short-term losses. ${ }^{63}$ The current differential charges can be viewed as a kind of tax, levied to upgrade the highway and pier to allow cars to board the ferries as easily as they can drive to the bridge. When "equal access" is complete, there will no longer be any good economic reason for charging AT\&T more for access than its competitors.

Second, the FCC for some time deliberately maintained a "price umbrella" over AT\&T's competitors. It refused to allow AT\&T to cut its prices to the level of its incremental costs, a refusal that allowed the

60. See MacAvoy \& Robinson, Losing by Judicial Policymaking: The First Year of the AT\&T Divestiture, 2 YALE J. ON REG. 225, 249 (1985).

61. See Kahn, The Uneasy Marriage of Regulation and Competition, TelEMATICs, Sept. 1984, at 1,13 (stating that the higher local access charge paid by AT\&T is inefficient because it requires AT\&T customers to pay more than the marginal cost of access).

62. Equal interconnection was to have been "complete" by September 1, 1986. See AT\&T, 552 F. Supp. at 233. The BOC's have not met this schedule. Furthermore, waivers are permissible in the case of many small offices, which serve up to $40 \%$ of the population. MacAvoy \& Robinson, supra note 60 , at $249 \mathrm{n} .96$.

63. The FCC has stated that the extra charges on AT\&T are just a temporary measure for this purpose. See Long Distance Competition: Hearings Before the Subcomm. on Communications of the Senate Comm. on Commerce, Science, and Transportation, 99th Cong., 1st Sess. 126-27 (1985) [hereinafter Senate Hearings] (statement of Charles Brown, Chairman, AT\&T); MacAvoy \& Robinson, supra note 60, at 258 (citing Patrick, On the Road to Telephone Deregulation, PuB. UT1L. ForT., Dec. 6, 1984, at 19). Nonetheless, AT\&T and several observers have doubted that the charges have served only this purpose. They assert that the extent of the extra charge has been far greater than necessary to compensate for the difference in service. See Senate Hearings, supra, at 126-27 (statement of Charles Brown, Chairman, AT\&T); MacAvoy \& Robinson, supra note 60, at 249. In addition, at least two observers have feared that the FCC would seize upon the residues of unequal interconnection as a reason to continue the differential charges indefinitely. See MacAvoy \& Robinson, supra note 60 , at 249. It is worth noting that several of AT\&T's competitors have indeed requested such extensions. See Senate Hearings, supra, at 126-27 (statement of Charles Brown, Chairman, AT\&T). 
ferry boats to offer lower priced, though higher cost, service. ${ }^{64}$

Third, the FCC imposes on AT\&T a set of administrative requirements that do not apply to AT\&T's competitors. When AT\&T wishes to change its rates, it must file a proposed tariff. AT\&T's competitors may then complain, the matter will be set for a hearing, and there is likely to be considerable delay before the rate takes effect. AT\&T thus loses the benefit of its new tariff for several months, and its competitors gain the opportunity for anticipatory response. ${ }^{65}$

Two arguments have been advanced in favor of handicapping AT\&T. First is the fear of predatory pricing. ${ }^{66}$ The argument is that if regulators do not keep AT\&T's prices high, AT\&T will price below its incremental costs in order to drive its competitors from the market and then raise prices high enough (and long enough) to recoup its losses (and more) before new firms, attracted by the higher prices, enter the market. This scenario is analogous to one in which the bridge, despite facing incremental costs of $50 \notin$ per crossing, were to react to the ferry's $40 \$$ charge by charging $30 \uparrow$ tolls for long enough to drive the ferry out of business. Furthermore, proponents of handicapping argue, the difficulty of determining whether a particular price is below marginal cost requires a preventive handicap. ${ }^{67}$

Yet one might ask why, in the post-divestiture world, regulation is necessary to prevent predatory pricing, particularly if AT\&T and its competitors are all ferryboats. AT\&T could not easily fund below-cost pricing in long distance service for an extended period by raising prices in its monopoly markets; to the extent that AT\&T retains any monopoly markets, they are small. ${ }^{68}$ Beyond this question, however, is a more fundamental one: Does AT\&T have a strong enough incentive to drive com-

64. The FCC had previously accomplished this end by requiring AT\&T to price its services at fully distributed cost; that is, to recover a ratable portion of all common costs out of each relevant service. Although the FCC recently abandoned this pricing practice, see Guidelines for Dominant Carriers' MTS Rates and Rate Structure Plans, 50 Fed. Reg. 42,945 (1985) (to be codified at 47 C.F.R. $\S 1$ ), it has been argued that even the FCC's current standards, while less onerous, still prevent AT\&T from lowering its prices to incremental cost. See Consumer Protection Hearings, supra note 53, at 11-12 (statement of Alfred C. Partoll, Vice President, AT\&T).

65. See Consumer Protection Hearings, supra note 52, at 11-12 (statement of Alfred C. Partoll, Vice President, AT\&T); Kahn, supra note 61, at 11.

66. A belief that AT\&T was engaging in predatory pricing of long distance service was a major reason that the Department of Justice sought to break up the company in the first place. United States v. AT\&T Co., 524 F. Supp. 1331, 1364-70 (D.D.C. 1981); MacAvoy \& Robinson, supra note 57, at 25-27. Charges of such predatory pricing are less common today, but are not unknown. See MacAvoy \& Robinson, supra note 60, at 258 (quoting Comments of the Dep't of Justice, In the Matter of Long-Run Regulation of AT\&T's Basic Domestic Interstate Services (Apr. 2, 1984), at 2).

67. See U.S. General Accounting Office, Telephone Communications: Bell OpERATING Company ENTRy INTO NEW LiNes of Business 10 (1986).

68. Markets in which AT\&T has been said still to possess monopoly power include intrastate toll service, 800 service, and international voice service. AT\&T has strenuously argued that it has no market power in these areas. Reply Comments of AT\&T, supra note 52, at 50-58. Even if AT\&T 
petitors from the market? To do so would likely invite either reregulation or an antitrust suit under section 2 of the Sherman Act, ${ }^{69}$ with the predatory pricing advanced as an "exclusionary practice" leading to monopoly power. But, if AT\&T did not drive its competitors from the field, how could it ever recoup what it lost by charging below-cost prices? When it raised its prices later $\mathrm{m}$ an effort to recoup, its competitors-still in the industry-would simply undersell it. ${ }^{70}$ In any event, why should regulators, rather than antitrust enforcers, decide whether predatory pricing exists? Of course, if AT\&T is a bridge, one might find cost complexities that argue for having regulators look for predatory pricing; but then one would face the countervailing risk that the regulators, by preventing the bridge from cutting prices to incremental costs, would destroy the whole point of allowing new competition, namely, creating a marketplace test for low-cost long distance service.

A second, and better, justification for handicapping AT\&T is an "infant industry" argument. AT\&T, it is claimed, has considerable name recognition and other historical advantages. If its competitors are protected for a while, they will eventually become strong enough to compete effectively.

This argument, while logical, is subject to the traditional attacks on "infant industry" protectionism. Given their growth and investment, do AT\&T's competitors, really need protection ? $^{71}$ Protection may discourage these "infants" from developing the efficient practices needed to make them viable future competitors. ${ }^{72}$ Why can't they find investors who will sustain them in the short term, given the prospect of efficiency and profits in the long run? ${ }^{73}$ Finally, how long should we tolerate higher prices today in the hope of lower prices and better products tomorrow? Will our telecommunications infants ever grow up?

It is also interesting to note that long-term handicapping is wasteful even if deregulation itself was wrongly conceived-even if (contrary to this Article's basic assumption) long distance service is a natural monopoly. In that case, forbidding AT\&T from cutting its prices would deprive consumers of the benefits of lower costs. Such a prohibition would sup-

has monopoly power in these sectors, however, they clearly constitute too small a portion of its business to provide a meaningful subsidy to competitive sectors.

69. 15 U.S.C. $\S 2$ (1982).

70. See Reply Comments of AT\&T, supra note 52, at 47-48.

71. According to AT\&T, MCI's revenues have grown from under $\$ 100$ million in 1978 to $\$ 2.5$ billion in 1985. GTE Sprint has increased its revenues from $\$ 50$ million to over $\$ 1$ billion in the same period. In 1985, MCI had assets of $\$ 3.89$ billion, GTE Sprint of over $\$ 1$ billion. See generally, Consumer Protection Hearings, supra note 53, app. at 3-6 (statement of Alfred Partoll, Vice President, AT\&T).

72. See Reply Comments of AT\&T, supra note 52, Attachment 1 at 11 (statement of Kenneth Arrow, Professor of Economics, Stanford University).

73. See id. at 11-12. 
port inefficient ferry boats in the presence of a bridge that could carry the traffic at lower social cost. Of course, if, as we have assumed, the long distance industry is not a natural monopoly-if it is structurally competitive-then once AT\&T's competitors become reasonably established, handicapping AT\&T simply interferes with the competitive process. It discourages the very price cutting that deregulation seeks to bring about.

This is not to say that it makes no difference whether AT\&T is a bridge or another ferry boat. It does make a difference, but not a difference that public policy can do much about now. Suppose, after all, that the "bridge-and-ferry boat" characterization of the problem is correct. Suppose that AT\&T's fixed costs consist not of steel or cables or rightsof-way, long since depreciated and written off, but of such hard-to-measure intangibles as "systems" costs or "experience," or a research group like Bell Laboratories, or other related advantages that make AT\&T a potentially lower-cost carrier than any of its competitors. Given existing deregulation, could we ever find this out? Would AT\&T be likely to prove its cost advantages by dropping its prices and driving all others from the market? As aforementioned, this would invite a monopoly suit under section 2 or re-regulation through congressional legislation. Why would AT\&T not tolerate a few competitors, keeping its prices high enough to earn extra profits for itself while keeping its competitors in business? General Motors was often accused of pursuing just such a strategy.

It would indeed be ironic were AT\&T to become, in this sense, a hypothetical General Motors. It would also cast an interesting light on institutional methods of carrying out deregulation. In both the airline and telephone industries, economists argued that economic evidence revealed structural competition. The evidence seemed stronger, however, in the case of airlines. The airlines presented Congress with practical examples of deregulation-in California and in Texas. Airline deregulation was introduced by legislation after congressional study and empirical agency experimentation. In contrast, telephone deregulators produced no comparable history of agency failure. Telephone deregulation was introduced by courts acting on complaints by regulators and private parties. In a sense, telecommunications deregulation is deregulation of, by, and (perhaps) for the mandarins. ${ }^{74}$

Whether or not deregulation was initially a good idea, it is now an accomplished fact. Although new competitors may need some period of direct protection, it is difficult to find any theoretical or practical reason to continue that protection indefinitely. Thus, I think it fair to count a

74. Of course, given the fact that the income effects of telephone deregulation are perverse, helping the business user at the expense of the residential customer, Congress might never have approved it. 
policy of protecting competitors, rather than competition, as one of the policy risks facing the newly deregulated world.

IV

RISK Three: Regulatory Policy Will FaIl iN

TREating Regulated Segments of

OTHERWISE DEREGULATED

INDUSTRIES

A third risk mherent in deregulation arises out of the relationship between newly competitive firms and other still regulated parts of the industry. We may be seeing a variation on the old "regulatory scenario," where regulated railroads urged the regulation of trucking and barge lines to prevent their own rates from being undercut by unregulated free competition. The problem that has arisen in telephone industry is that deregulated competition for long distance calls will force local regulators to respond with changes in the structure of local and long distance calling prices. The policy risk is that regulators will not base their response upon economically sound principles of regulation.

\section{A. The Problem of Bypassing}

The problem arises not from the breakup of AT\&T, but rather from the initial decision of courts and regulators to allow new firms into the long distance business. The deregulatory vision was that competing carriers would continue to connect customers to their long distance lines through the established local exchanges. ${ }^{75}$ However, new technological developments, especially microwave, have made it feasible for these companies, as well as AT\&T, to bypass the local companies in connecting certain large customers. ${ }^{76}$ Firms can offer, and major customers can buy, long distance telephone service that does not use the existing lines and switching belonging to the (former) Bell system.

Returning to the bridge example will help to illustrate this problem. Whether or not the bridge offers a good analogy for long distance service, it does provide a local service analogy. The scenario, again, is that the bridge has high fixed sunk costs. The possibility of using ferry boats to bypass the bridge is real. The ferry boat has total costs that may well be greater than the incremental costs, but less than the average costs, of

75. This assumption is implicit in the consent decree's equal access requirement. $A T \& T, 552$ F. Supp. at 232-34. The judgment court has recently indicated that it expects most customers to continue to receive long distance service by this means for some time. United States v. Western Elec. Co., 627 F. Supp. 1090, 1095 n.16 (D.D.C. 1986).

76. See NTIA, supra note 52, at 116. In approving the consent decree, the district court explicitly recognized the existence of this technology and gave AT\&T permission to use it. $A T \& T$, 552 F. Supp. at 175-76. 
using the bridge. But only a few special kinds of users-say trucks-can use the ferry boat. The analogy to local telephone service is a good one. The local systems have large sunk costs. Certain large businesses can bypass the system on certain kinds of calls by using technology that involves lower average costs than the average costs of going through the local system. But if the incremental costs of bypassing are higher than the incremental costs of traditional routing, then the lower price of bypassing encourages economic waste.

Insofar as this description fits current circumstances, the stage is set for a kind of tragedy. ${ }^{77}$ How can business customers be prevented from deserting the present local system when they make long distance calls? The obvious economic answer is by lowering the price of their existing service. Just as trucks can be kept on the bridge by cutting truck tolls, so businesses can be convinced to use the local network for long distance dialing by lowering the charge. Moreover, there is a logical answer for any other customer who objects: If the bridge does not lower the truck toll, trucks will desert it for the ferry, and fewer customers will remain to share the cost of the bridge. Each of these customers will then have to pay even more than if the bridge had cut the truck toll. How far the bridge must cut the truck toll to prevent truck desertion is, however, a difficult empirical question, particularly in the telephone context, where tolls must cover categories of users. Insofar as a toll is cut more than necessary to prevent desertion, the cut burdens other users with unnecessarily high tolls.

The strategy of reducing telephone rates in order to prevent bypassing by long distance callers is further complicated by certain special features that have until now characterized telecommunications pricing. First, long distance calls traditionally have been priced so that the contribution each long distance call makes to the cost of the local service needed to connect it is far higher than the contribution each purely local call makes to the same cost. ${ }^{78}$ The purpose of this difference in contribution has been to ensure the nearly universal availability of local service to the American public. ${ }^{79}$ Second, commercial callers have paid proportionately more for telephone service in order to secure lower rates for residential users. ${ }^{80}$ Finally, urban users have paid prices above cost so that the high costs involved in serving rural areas would not result in prohibitive prices there. ${ }^{81}$ The net effect of these three sets of price differ-

77. See MacAvoy \& Robinson, supra note 60, at 250-51.

78. See Kahn, The Road to More Intelligent Telephone Pricing, 1 YALE J. ON REG. 139, 141-44 (1984); MacAvoy \& Robinson, supra note 57, at 49; MacAvoy \& Robinson, supra note 60, at 228 . 32.

79. See MacAvoy \& Robinson, supra note 57, at 2-3.

80. See id. at 4 .

81. This pricing feature is accomplished through a process known as "averaging," by which 
ences has been a substantial excess charge on large commercial callers. It is as if the bridge, prior to ferry boat entry, charged trucks far more for crossing than it charged other vehicles. This difference did not matter (at least for our purposes) so long as AT\&T had a monopoly on long distance service. The result today, however, is that the local price cuts that are necessary to retain the large customers are far greater than they might otherwise have been, thus producing greater political resistance from those who will be burdened with higher rates. ${ }^{82}$ In addition, any solution to the bypassing problem must be sensitive to the need to maintain universal service as mandated both by law $^{83}$ and by social considerations.

The problem, then, is that the price cuts to large businesses necessary to prevent bypassing, with its attendant economic waste and harm to consumers, are likely to encounter political resistance and to compromise the goal of universal service.

\section{B. Preventing Bypassing}

Three possible approaches to the problem are apparent. First, one might try to restore the pre-regulation status quo. ${ }^{84}$ To do this, the local companies would have to assess a heavier access charge on all long distance carriers. This charge-which the carriers would then pass on to consumers in the form of higher rates-would prove the equivalent of the effectively higher contribution that the unified AT\&T once provided to local service by charging more for long distance. At the same time, the regulator would impose some kind of tax on carriers not connected to any local system, the proceeds from which would support the local carriers. This tax would raise the price of bypass service to the level of traditional service so that bypassing would not pay.

This type of solution amounts to the banning of ferry boats by taxing them out of existence. Such an approach is subject to both practical and theoretical objections. On the practical level, the tax on bypassing carriers is likely to be extremely difficult both to devise and to enforce. The principal difficulty in devising the tax would be setting it at a level high enough to discourage uneconomic bypassing and yet low enough not to obstruct the introduction of systems that in fact involve lower incremental costs than traditional routing. ${ }^{85}$ Other problems would arise from the inevitable pressures to provide exemptions from the tax to cer-

long distance customers in all parts of the country pay the same rates regardless of the costs of serving them. See Reply Comments of AT\&T, supra note 52, at 58-59; Kahn, supra note 78, at 144; MacAvoy \& Robinson, supra note 57, at 4.

82. See Kahn, supra note 78, at 150-51; MacAvoy \& Robinson, supra note 60, at 241-42.

83. 47 U.S.C. $\$ 151$ (1982).

84. This possibility is discussed and deemed "unworkable" in NTIA, supra note 52, at 117-18.

85. See id. at 114-15 \& n.28. 
tain users, such as government. ${ }^{86}$ On the enforcement level, it is often difficult to identify which calls made on nontraditional media are long distance, even with current technology ${ }^{87}$-and technologies making detection even more difficult would undoubtedly arise were a tax system to provide an incentive for their development.

On the theoretical level, the solution of imposing access charges and bypass taxes, even if properly enforced, would create economic waste. The most serious problem is that it discourages long distance calling where the user is willing to pay more than the incremental cost of the call, but will not pay that incremental cost plus a large amount of fixed sunk cost plus a large subsidy for, say, rural service. This problem is that of the bridge crosser who would pay $\$ 1.00$ but not $\$ 1.50$ to cross the bridge. To be fair, this problem has nothing at all to do with deregulation; it would exist as long as the regulator is determined to hold local prices down by obtaining a large share of fixed, sunk costs from the long distance caller. And the only criticism one can make of this is to ask the regulator why he is doing it. Is there something virtuous about local calling or wicked about long distance? Is it that those who make local calls are poorer and this is a form of income transfer? How do we know? Who buys the products made by firms that call long distance? Are they farmers selling food? In the airline industry (some observers believe), regulators for many years charged more for long distance routes in order to subsidize shorter service. Why, asked Professor Caves, should a grandmother flying from Boston to Los Angeles pay more so that a businessman flying from Utica to Buffalo can pay less? ${ }^{88}$ This is not to say that there are not good social reasons for making local service available to every citizen. However, narrower, targeted subsidies, such as the lifeline service that has been introduced in some communities, ${ }^{89}$ would seem a better way to further this social goal. It is hard to see why affordable local service should come at the expense of permitting long distance rates to reflect the lower costs that technological progress has made possible.

A second way of dealing with the problem is basically to do nothing. One can simply impose specially cumbersome burdens of proof upon those who would lower the access charge, hence lowering long distance

86. See id. at $117-18$.

87. See id. at 117 .

88. See R. Caves, Air Transport and Its Regulators: AN Industry Study 435-36 (1962).

89. One proposal, for example, would allow low income users unlimited free calls to five preselected numbers, while charging on a measured basis for all other calls. See NTIA, supra note 52, at 122; see also Kahn, supro note 78, at 145-58 (suggesting that "telephone stamps," analogous to food stamps, could be issued to those targeted as genuinely poor). The CAB's change of policy during the 1950's, deemphasizing subsidy of short-haul routes out of trunk line fares in favor of directly subsidizing independent local carriers, is in some sense similar. See R. CAVES, supra note 88 , at $435-36$. 
rates to levels closer to the costs of providing long distance service. If one requires definite proof that in the absence of a lower charge, there will be sufficient bypassing to impose still greater charges on residential users, the burdens are not likely to be met. Moreover, regulators may accept one or more of several newly hatched economic theories, ${ }^{90}$ apparently designed to show that long distance callers ought to pay more for the local portion of their calls than other local callers. This second approach however, would be tragic, for it will lead to desertion through bypassing and eventually to higher costs for the remaining users.

Third, the regulators might devise an economically-oriented system of charges so as to align more closely the prices of various services with the incremental costs of providing those services. Professor Kahn has provided numerous suggestions regarding such a system. ${ }^{91}$ Among other possibilities, local service might be measured and charges assessed accordingly. Charges in older areas of the city (hooked up permanently to local networks in the past) might be lowered while connection charges in newer areas might be raised. These proposals would allow regulators to lower the access charges for long distance service while at the same time concentrating the costs of local service on those who create most of those costs and who, as a rule, are most able to bear them. ${ }^{92}$ To the extent that local rates might still be prohibitive to particularly needy customers, targeted subsidies might best address their concerns.

I favor the third method for dealing with the bypassing problem. Access charges plus a bypass tax threaten to forfeit the benefits both of deregulation and of technological change, while ignoring the problem threatens to hurt the residential consumer. Cost-based charging is consistent with a procompetitive theory of regulation that sees regulation, at least in part, as an effort to bring to the consumer at least some of the advantages of economic efficiency where the market cannot be relied upon to do the job. I shall leave the reader to find the details of the necessary changes in Professor Kahn's work. ${ }^{93}$ Here, I simply point out that the danger of not following sound economic principles when regulating segments of otherwise deregulated industries is one of the major risks facing the public in the newly deregulated world.

90. See Kahn, supra note 78 , at $142-43,144-45$.

91. See id. at 147-48, 155-57; Kahn, The Next Steps in Teleeommunications Regulation and Research, PUB. UTIL. FoRT., July 19, 1984, at 13; Kahn, supra note 61, at 14-15.

92. People who make many local calls, for instance, may be wealthier than those who make few such calls. Similarly, there may be a correlation between residence in a newly developed area and ability to bear the additional costs of connection to such an area. Of course, the distribution of wealth may not follow the distribution of costs in all instances. Where there is a correlation, however, the argument for economically based charges is especially strong.

93. See supra notes 61,78 , and 91 . 


\section{Risk Four: ANTITRust Policy WILL BE UNABLE to \\ Prevent ANTICOMPETITIVE BotTlenecks IN Partially DEREgulated INDUSTRIES}

\section{A. The Problem of Bottlenecks}

A final risk arising in the newly deregulated industries involves the inability to deal with residual elements of monopoly power, actual or potential. Deregulation, after all, did not come about in the airline or telecommunications industries because anyone thought them perfectly competitive. Rather, those urging deregulation felt that on balance the evils of regulation exceeded those of relying upon free markets protected by antitrust. In each industry, there remain residual areas of potential market power, sometimes called "bottlenecks,"94 which, at least in the short run, threaten significant anticompetitive harm.

A useful example of a bottleneck in the airline industry arises out of the recent controversy about the computerized reservation systems (CRS's), owned and supplied to travel agents by American Airlines and United Airlines. ${ }^{95}$ Critics claim that American and United design their CRS screens to favor their own flights, thereby placing competing airlines at a disadvantage. ${ }^{96}$ These critics also note that competitors cannot replicate the United or American CRS's because of the prohibitive costs of creating a CRS and a shortage of skilled programmers. ${ }^{97}$ In addition, because high fixed costs make a large scale operation more efficient, new entrants would need to capture a fairly large market share before they could compete with the dominant carriers. ${ }^{98}$ Finally, travel agents are most likely to buy the system supplied by the airline that is dominant in their region, and once they buy one system, they are unlikely to switch. These facts, the critics conclude, make the CRS a kind of regional natu-

94. For an explanation of the term "bottleneck," see 3 P. AREida \& H. HovenKAMP, ANTITRUST LAW If 736.1, at 492 (Supp. 1986).

95. Bottlenecks also arise in the form of limited space at certain airports, preventing competing airlines from landing as many planes as they wish.

96. See Computer Reservation Systems: Hearings Before the Subcomm. on Aviation of the Senate Comm. on Commerce, Science, and Transportation, 99th Cong., lst Sess., 4 (1985) [hereinafter 1985 CRS Hearings] (statement of Matthew Scocozza, Assistant Secretary, Dep't of Transportation); Review of Airline Deregulation and Sunset of the Civil Aeronautics Board (Airline Computer Reservations Systems): Hearings Before the Subcomm. on Aviation of the House Comm. on Public Works and Transportation, 98th Cong., 1st Sess., 71-74 (1983) (CAB report to Congress).

97. In 1984, United claimed to have made expenditures of $\$ 500$ million on its APOLLO system. See Notice of Proposed Rulemaking, 49 Fed. Reg. 11,644, 11,650 (1984). American reported development costs of $\$ 160$ million and an investment of $\$ 350$ million by 1985 . 1d.; see a/so 1985 CRS Hearings, supra note 96, at 85 (prepared statement of Robert Crandall, President, American Airlines).

98. See Notice of Proposed Rulemaking, 49 Fed. Reg. 11,644, 11,650. Systems owned by other airlines-TWA's PARS system, Delta's DATAS II, and Eastern's SODA-altogether account for only a $19 \%$ market share. See id. at 11,649 . 
ral monopoly, the control of which allows an airline to injure or destroy competition in the entire airline industry. ${ }^{99}$

A similar argument against integrated operation in adjacent industries is raised against local telephone operating companies. Local companies are still regulated because they possess significant monopoly power in local markets. To what extent should they be allowed to expand into other businesses-either businesses such as telephone equipment, which supply ingredients of the telephone system, or businesses such as information processing, which use local communications extensively as part of the product that they sell? Some fear that the ability of the BOC's to control local telecommunications while offering these other services would give them an unfair advantage, allowing them to distort or destroy competition in these other fields.

What shall we do with these bottlenecks? Should we isolate them, forbidding their owners to enter other related businesses? Or should we regulate them in an effort to control abuses inherent in integrated ownership?

Antitrust law has varied in its treatment of bottlenecks. The different treatments are perhaps best illustrated by comparing a classic Suprene Court case with a hypothetical situation. The original and most famous "bottleneck control" case is United States v. Terminal Railroad Association. ${ }^{100}$ A combination of railroads had acquired exclusive control of all railroad terminals in St. Louis and imposed discriminatory charges upon their competitors for use of the facilities. The Supreme Court held that the unification was an unlawful combination in restraint of trade and "an attempt to monopolize commerce among the States which must pass through the gateway at St. Louis." 101 Because the unified system provided more efficient service than separately managed terminals, however, the Court refused to order immediate dissolution of the combination, and instead ordered the association to admit its competition to the facilities on equal terms. ${ }^{102}$

In contrast, consider the following hypothetical. Suppose that George and Edward invent a better spring for a traditional mousetrap that they produce in competition between themselves and with others. As in the case of the railroads, George and Edward's exclusive control over the spring will hinder-perhaps decisively-other competitors in the mousetrap market. Antitrust law, however, will not impose equal access requirements upon George and Edward. It will not require them

99. See 1985 CRS Hearings, supra note 96, at 35-36 (statement of Lamar Muse, Chairman, Muse Air Corp.).

100. 224 U.S. 383 (1912).

101. Id. at 409.

102. Id. at $410-13$. 
to provide their mousetrap competitors with the spring on "fair" or "equal" terms, nor will it require them to set up a separate spring company and divest it. ${ }^{103}$

The reason for this different treatment lies in the need to favor efficiency and encourage innovation. Restraining railroads from excluding their competitors from gateway passage is unlikely to have an adverse effect upon the construction or maintenance of gateways. But requiring an inventor, even of an unpatented invention, to give his secrets away to his competitors discourages innovation and invites unwieldy court supervision in an effort to determine "fair" terms. That is why courts have struck down or tried to supervise very few bottlenecks-and virtually none where the bottleneck was created by a single firm, rather than by agreement among several competing companies.

To understand one's different intuitive reactions to these two examples, particularly in the present deregulatory context, consider the following pairs of questions. First, compare:

(1) Should an airline be permitted to provide a computerized reservation service for travel agents? with

(2) Should an owner of a computerized reservation service be permitted to provide airline service?

Then compare:

(1) Should a local telephone company be allowed to enter an "information service" industry? with

(2) Should a firm that sells an "information service" be allowed to provide local telephone service?

In the first pair, an affirmative answer to either question approves a single integrated firm offering both CRS and airline service; in the second, an affirmative answer to either question approves a single integrated firm providing both information and local telephone service. In both pairs, however, the second question is phrased so that it seems to call more quickly and more easily for an affirmative response. One's responses to the first and second questions differ because the first questions-like the Terminal Railroad case-focus attention upon the likely anticompetitive features of the integration, whereas the second questions-like the mousetrap case-focus attention on potential competitive benefits.

The preceding examples suggest that analyzing these deregulatory "leftover" bottlenecks may be simpler than it first appears. We need only ask the most basic of antitrust questions: (1) What are the likely anticompetitive effects of the integration? and (2) What are the potential

103. See GAF Corp. v. Eastman Kodak Co., 519 F. Supp. 1203 (S.D.N.Y. 1981). Professor Areeda uses an example that I have copied here. See P. AReEdA, ANTITRUst ANalysis 525-26 (3d ed. 1981). 
countervailing economic virtues? We might also ask: (3) Which institution-antitrust or regulation - can more effectively identify and weigh the relevant factors and take curative action?

\section{B. Some Bottlenecks Examined}

These basic questions will be considered with respect to both the computerized reservation systems in the airlines and the integrated services in the telecommunications industry.

\section{Computerized Airline Reservation Systems}

Critics identify three serious risks of anticompetitive harm. First, they argue that the CRS-owning airlines bias the programs and displays in their own favor. ${ }^{104}$ Carrier $A$, for example, may use a computer algorithin that lists all of its own connections before it lists any connection with other airlines. ${ }^{105}$ Or it inay list carriers with which $A$ maintains a marketing relationship before it lists other carriers, ${ }^{106}$ or it may make up a supposedly neutral order for display-say, "list carriers in order of elapsed time"-but then use fake elapsed times to make certain the coinputer displays $A$ and its friends first. ${ }^{107}$ To address this problem, the $\mathrm{CAB}$ issued a rule requiring CRS owners to offer unbiased display screens. ${ }^{108}$ But, the critics said, CRS owners circumvented the rule by offering subscribing agents two display screens-the first complying with the $\mathrm{CAB}$ regulation and the second biased in their own favor. ${ }^{109}$ The owners then offered incentives to agents to use the "secondary" displays, by tailoring fees to the number of bookings made from those screens. ${ }^{110}$ The owners also offered a "lock-in" device that autoinatically displays the "secondary" screen when the terminals are turned on in the morning, altogether bypassing the unbiased screens. ${ }^{111}$ The combination of financial inducements and the lock-in mechanism, critics said, effectively reversed the priority of the primary and secondary screens, so that travel

104. See supra note 96.

105. See 1985 CRS Hearings, supra note 96, at 49 (prepared statement of Phil Bakes, President, Continental Airlines); id. at 110-11 (statement of Gary Adamson, President Air Midwest).

106. See id. at 49 (prepared statement of Phil Bakes, President, Continental Airlines).

107. Third Party Complaint of Delta Air Lines, Ine. at 11-14, Delta Air Lines, Inc. v. American Airlines, Inc., No. 44094 (U.S. Dep't of Transportation, filed June 16, 1986) (arguing that American Airlines' manipulation of "elapsed times," which are the total times between published departure and arrival times, resulted in CRS displays which favored American Airlines over other carriers).

108. 14 C.F.R. $\$ 255.4$ (1986).

109. See 1985 CRS Hearings, supra note 96, at 30 (statement of Daniel May, President, Republic Airlines). At least one critie claims that the primary screens remain biased. See id. at 68 (statement of Phil Bakes, President, Continental Airlines).

110. See id. at 132-33 (prepared statement of Alfred Kahn, Professor of Political Economy, Cornell University).

111. See id. at 62 (prepared statement of Northwest Airlines). 
agents and their customers continued to learn less, or later, about the flights of competitors. The traveler was unlikely to learn enough about what was occurring to punish the travel agents who used "biased" screens by switching to travel agents who did not. The result was faulty or incomplete information that distorted consumer choice. Recently, however, American Airlines, United, and TWA agreed voluntarily to end the secondary display bias. ${ }^{112}$

Second, a synergy between airline ownership and ownership of a CRS permits the CRS-owning carrier to protect its market position in both the CRS and airline industries. An airline dominant in a particular region can offer powerful inducements to travel agents in that area to use its CRS system. ${ }^{113}$ Thus, in Denver, an important United Airlines hub, United's APPOLO system accounted for seventy-two percent of the market, and in Dallas, an American Airlines hub, American's SABRE system accounted for eighty-eight percent of the market. ${ }^{114}$

Once a CRS-owning airline has achieved dominance in a particular regional CRS market, it can use its dominance to protect its market position in the airline industry. ${ }^{115}$ Airline market entry is hindered not only by the usual difficulties confronting entrants in a particular airline market, such as finding space at the airports, but also by a biased reservation system.

This problem could be serious because the airline industry is competitive in a special sense: Many routes can support only one or two firms, so potential competition from other nearby carriers is important in disciplining the dominant carrier. The higher the entry barriers, the less effective the discipline. For reasons earlier discussed, ${ }^{116}$ one should be reluctant to allow any significant additional barrier to entry.

Third, the critics argue that an owner may use information stored in the CRS about each passenger's itinerary, class of service, fare code, and so forth, for anticompetitive purposes. The CRS affords direct, immediate access to the proprietary information of each carrier. ${ }^{117}$ This infor-

112. See id. at 13 (statement of Matthew Scocozza, Assistant Secretary, Dep't of Transportation).

113. Travel agents will naturally prefer to use the CRS providing the most accurate data about the carrier with whom they place the most bookings. See Notice of Proposed Rulemaking, 49 Fcd. Reg. 11,644, 11,652. By providing competitors with inaccurate information about its flights-or no information at ail-the CRS-owning carrier can seriously impede its competition in the CRS industry. See 1985 CRS Hearings, supra note 96, at 131 (statement of Alfred Kahn, Professor of Political Economy, Cornell University).

114. See 49 Fed. Reg. at 11,649.

115. See 1985 CRS Hearings, supra note 96, at 32 (statement of Daniel May, President, Republic Airlines).

116. See supra text accompanying notes $30-33$.

117. See id. at 26-27 (statement of Charles Rule, Deputy Assistant Attorney General, Antitrust Division). 
mation offers valuable insights into market responses to new fares, routes, or services. ${ }^{118}$ Although the $\mathrm{CAB}$ requires American and United to share with their competitors any marketing data they generate on computer printouts, ${ }^{119}$ this requirement is easily circumvented. The CRS owners can simply display the information on their own terminals without printing it out. They can also secure a competitive advantage by delaying the transfer of, and charging high prices for, any information they do print out. ${ }^{120}$

Moreover, the exchange of information itself poses an anticompetitive threat even if the CRS owners do not use their competitors' proprietary information unfairly. The immediate communication of marketing data made possible through the use of CRS's increases the likelihood of tacit cooperative agreements. The more concentrated regional markets become, the greater the risk that such information-sharing will inhibit competition by encouraging oligopolistic coordination. ${ }^{121}$

Given these apparently significant anticompetitive risks, what are the countervailing economic benefits that favor ownership of CRS's by airlines? The CRS is primarily an information display program; a separate firm may not be able to gather the necessary information as readily as an airline can gather information about the schedules of its competitors. The airlines and the Department of Justice argue that there are significant efficiencies involved in integrating the computer operations involved in CRS's with the airlines' internal reservations systems. ${ }^{122}$ Whether one could preserve these efficiencies while allowing other smaller airlines to participate in the ownerslip of a CRS, or after requiring divestiture, is a subject of considerable debate.

The need to encourage innovation also justifies allowing integrated ownership to continue. The airline owners of CRS's invested money in developing them. Their investment succeeded. Antitrust courts are reluctant to forbid vertical integration that flows from internal expansion, particularly expansion that was successful in the marketplace. It is a little as if one tried to take George and Edward's mousetrap spring away from them. It is no wonder, then, that the Department of Justice and earlier regulatory authorities tried to control the anticompetitive effects

118. See id. at 31 (statement of Daniel May, President, Republic Airlines).

119. 14 C.F.R. $\S 255.8$ (1986).

120. See 1985 CRS Hearings, supra note 96, at 17 (statement of Charles Rule, Deputy Assistant Attorney General, Antitrust Division); id. at 31 (statement of Daniel May, President, Republic Airlines); id. at 50 (prepared statement of Phil Bakes, President, Continental Airlines).

121. See United States v. Container Corp. of America, 393 U.S. 333 (1969) (exchange of price information among regional competitors held to encourage changed policies); Sugar Inst. v. United States, 297 U.S. 553 (1936) (collection and dissemination of sales and production statistics by trade association held to be an unreasonable restraint on trade).

122. See 1985 CRS Hearings, supra note 96, at 25 (prepared statement of Charles Rule, Deputy Assistant Attorney General, Antitrust Division). 
of the ownership-insisting upon "unbiased" displays, prohibiting certain price discrimination, and so forth-rather than requiring divestiture.

Nonetheless, certain special circumstances weaken the force of this traditional argument. The CRS-owning airlines have by now presumably made considerable profit from their investment in CRS's. The systems are well enough developed so that a sale would likely reward them with the capitalized value of potential future profit. Further, there is some antitrust precedent that suggests that an initially procompetitive venture might, after achieving its procompetitive purposes, become anticompetitive; at that later time, more drastic remedies may become appropriate. ${ }^{123}$ Finally, the airlines were regulated when they entered the CRS business. American and United, the largest CRS owners, were also the largest regulated carriers. One might ask to what extent such regulated investment is entitled to a more than reasonable return. Is it then more fair (or less unfair) to force divestiture upon such a firm once it has earned a generous profit on its investment if (1) the anticompetitive risks are significant, (2) the other economic justifications for integration seem relatively weak, or (3) the government finds it difficult to regulate effects alone?

I shall stop here, noting that the arguments about CRS's may come down to questions about what relief can practically be ordered: Divestiture, forced adinission of other airlines to ownership, or enforcement of "anti-bias" rules. To decide what form of relief is practical would require further examination of the facts-particularly those related to efficiencies of integration.

\section{Integrated Telephone Service}

A similar problem exists in the newly deregulated telecommunications industry, where the local telephone companies are left behind as regulated pockets of monopoly power. Regulators are asking whether they should isolate the Bell Operating Companies (BOC's) or allow them to enter related businesses, such as the provision of various information services or long distance telecommunications. ${ }^{124}$

123. See United States v. Pan Am World Airways, 193 F. Supp. 18 (S.D.N.Y. 1961), rev'd on other grounds, 371 U.S. 296 (1963).

124. The AT\&T consent decree, on its face, essentially forbids the BOC's from engaging in any business other than local and intraexchange telephone service. $A T \& T, 552 \mathrm{~F}$. Supp. at 227-28. The decree also provides, however, for removal of these restrictions "upon a showing ... that there is no substantial possibility that [the BOC] could use its monopoly power to impede competition in the market it seeks to enter." Id. at 231; see also id. at 186-95 (discussing restrietions on BOC's). The district court subsequently promulgated procedures for granting waivers from the restrictions in individual cases. United States v. Western Elec. Co., 592 F. Supp. 846, $873-74$ (D.D.C. 1984), appeal dismissed, 777 F.2d 23 (D.C. Cir. 1985). At the same time, it has forbidden BOC expansion into most telecommunications fields. See id. at 867-68; United States v. Western Elec. Co., 627 F. Supp. 1090 (D.D.C. 1986). 
Several arguments are typically advanced against allowing the BOC's to provide integrated service. Some of them are better than others.

First, there is a simple "deep pocket" argument. It claims that the BOC's may use the profit from their monopoly communications businesses to subsidize "below cost" prices in their competitive businesses. In this simple form, ${ }^{125}$ the argument suffers the defect of all "deep pocket" arguments; it proves too much. If taken literally, it would prevent any firm with substantial resources from entermg any line of business for fear that it would use its resources to drive competitors from the field and then raise prices. It assumes the antitrust laws are incapable of dealing with the "predatory" below-cost prices that are preconditions of this argument. And by preventing competition now, it effectively throws out the baby with the bathwater.

This argument is particularly difficult to make plausible in the context of telecommunications. Several other competitors or potential competitors, such as IBM (which owns a substantial portion of MCI), have resources at least as great as the BOC's. ${ }^{126}$ Furthermore, regulation of local monopolies creates, if anything, less reason to fear a "deep pocket" than usual, because regulation, insofar as it is effective, prevents monopoly profits and therefore means the pocket is not unfairly deep. ${ }^{127}$

Second, critics claim that to allow BOC's to enter related fields will replicate the problem of integration that led to the antitrust suit against AT\&T. This argument is simply mistaken, and it is important to understand why.

The problem that led to the AT\&T suit was not simply the problem of vertical integration. The government did not claim that a natural monopoly should do no business in any competitive sectors. It did not

125. A more sophisticated form of this argument-that the BOC's may persuade the regulators improperly to include costs of the competitive enterprise in the monopoly rate base-is discussed infra at text accompanying notes 130-135.

126. In 1984, IBM had assets of $\$ 42.8$ billion. Consumer Protection Hearings, supra note 53, at 292 (statement of Alfred C. Partoll, Executive Vice President, AT\&T). Bell South, the largest of the BOC's, had assets of $\$ 23.7$ billion. NTIA, supra note 52, at 65 n.31.

127. In enforcing the AT\&T consent decree, the judgment court has imposed a variety of restrictions upon BOC entry iuto fields related and unrelated to telephone service. Western Electric, 592 F. Supp. at 868-72. But see Schwartz, Diversification and Regulated Industries-What's Next for the Telephone Holding Companies?, 7 ComM./ENT. L.J. 195, 216-17 (1985) (arguing that these restrictions are of little practical effect). Some of the court's language suggests that it imposed these restrictions in part out of a fear of simple predation. $592 \mathrm{~F}$. Supp. at 853 . Other lauguage, however, indicates that the court was focusing ou the more plausible danger of misallocation. Id. at 863-64; see also United States v. Western Elec. Co., 1986-1 Trade Cas. (CCH) 凤 66,987, at 62,057-58 (D.D.C. Feb. 26, 1986) (mere size is "not [a] legitimate obstacle[" to diversification). It is also interesting that, iu approving GTE's acquisition of Sprint long distance service, the same court considered GTE's "deep pocket" an argument in favor of the merger. See United States v. GTE Corp., 603 F. Supp. 730, 735-36 (D.D.C. 1984). 
argue, for example, that a natural gas distributor should be forbidden to sell heating system filters, or that a railroad could not sell souvenir menus-or that an airline (when regulated) should not be permitted to offer charter service. Rather, the government claimed that the natural monopoly controlled a large portion of the market in the competitive sector. ${ }^{128}$ AT\&T controlled (through Western Electric) more than eighty percent of the equipment manufacturing business; it controlled more than seventy percent of long distance telecommunications. ${ }^{129}$ In this context, the integration was viewed as unlawful because it helped to perpetuate an already existing monopoly share of an important competitively structured industry.

In the case of the BOC's, the circumstance of their integration or internal expansion is critically different. The issue is whether the BOC's should be allowed to enter different markets, or various competitive mdustries, where they now account for zero percent, not seventy percent, of the competitive marketplace. Such entry raises a potential problem only if the BOC's would have both the incentive and the ability to use their local exchange monopolies in those related fields unfairly, in a way that improperly allows them eventually to dominate or to monopolize those fields.

The opponents of BOC entry make the more serious and important claim that the risk of improper or unfair competition, and even eventual BOC dominance, is great. In support, they present two arguments. ${ }^{130}$

The first argument is that firms may misallocate costs from their competitive businesses to their monopoly service. To the extent that this argument simply restates the Averch-Johnson effect, ${ }^{131}$ it is weak. A regulated monopoly has an incentive to pad its rate base if it can borrow money at a rate lower than its allowed return on investment. For example, if a regulated telephone company can borrow money at eight percent, it will borrow as much as possible, build pyramids with it, and collect a nine-percent return from the users of telephone service, as long

128. See United States v. AT\&T, 524 F. Supp. 1336, 1346 (D.D.C. 1981).

129. See Second Computer Inquiry, 77 F.C.C.2d 384, 471 (1980); United States v. American Tel. \& Tel. Co., 552 F. Supp. 131, 171 (D.D.C. 1982); see also MacAvoy \& Robinson, supra note 57, at 3 (suggesting that AT\&T had an even greater share of the telecommunications market).

130. A third argument, heavily relied upon by the court in enforcing the consent decree, is that diversification may distract a BOC from its principal task of providing excellent local service. Western Electric, 592 F. Supp. at 858-67; 627 F. Supp. at $1096 \mathrm{n} .18$ (same case). It is unclear, however, that diversified companies are less efficient or innovative than those that produce a single product. But see Schwartz, supra note 127, at 201-14 (pointing out difficulties inherent in diversified operation). Furthermore, new technology, with its accompanying threat of local system bypass, will provide the local BOC's with continued incentive to operate efficiently. See supra text accompanying notes 75-93.

131. See Averch \& Johnson, Behavior of the Firm Under Regulatory Constraint, 52 AM. Econ. REV. 1052 (1962). 
as the regulator allows nine percent and doesn't catch the padding. If the rate-base padding consists of investment in a related competitive service, such as some kind of information service, the cost of which is partly and improperly charged to local telephone service, it may be hard to detect. Still, it is not likely that the regulator would allow the local telephone company a higher rate of return than the cost of capital, at least not in the near future when regulators are desperately trying to minimize the increase in local residential rates made necessary by deregulation. If so, the Averch-Johnson problem does not seem likely to have major empirical significance.

Even without the Averch-Johnson effect, however, firms may still be able to profit from misallocation of costs. The Averch-Johnson effect depends upon returns higher than the cost of capital because investment in pyramids is not in itself profitable. A BOC may, however, be able to enter a related busmess that would itself provide an adequate return on capital. In that case, any return which the regulator allows on the investment, even if less than the cost of capital, is supracompetitive-that is, excess profit. ${ }^{132}$ The BOC might pocket this profit and get rich on the backs of its ratepayers. Alternatively, it might correspondingly lower its prices in the coinpetitive market and thus gain a decisive advantage over its rivals, despite facing the same real costs that they do. ${ }^{133}$ In either event, the public loses.

The plausibility of this scenario depends upon whether the BOC's will be able to slip misallocation by the regulators. Certainly, regulators are unlikely, in this era of concern for local rates, to ignore potential ratebase padding. Furthermore, to the extent that the BOC's are currently earning less than a fair return on their local investment, padding becomes both less attractive and less troublesome, and may to a degree even be viewed as merely compensatory. ${ }^{134}$ On the other hand, the similarities of the various telecommunications industries, combined with the real possibility of genuine economies from integration, may make some padding

132. This analysis assumes that the investment is in fact useful only in the competitive sector. To the extent that costs are common between the monopoly and competitive enterprises, it may not be inefficient for monopoly customers to bear most or all of these costs. To the extent that investment would be necessary to provide the monopoly service in any event, there is no excess profit if customers in the competitive sector receive a free ride. See Reply Comments of AT\&T, supra note 52, Attachment 1 at 12-22 (statement of Kenneth J. Arrow, Professor of Economics, Stanford University). The concern of some enforcers about misallocation of common costs thus appears somewhat confused. See, e.g., Western Electric, 592 F. Supp. at 853.

133. See generally T. Brennan, Regulated Firms in Unregulated Markets: Understanding the Divestiture in U.S. v. AT\&T 17-23 (1986) (draft of unpublished manuscript, on file with author) (discussing the risk that a firm operating in both a regulated market and an unregulated market may use profits from the regulated market to gain a competitive advantage in the unregulated market).

134. See MacAvoy \& Robinson, supra note 60 , at 255 ; NT1A, supra note 52 , at $45,75-76$ (concluding that BOC's are unlikely to cross-subsidize). 
very difficult to detect. ${ }^{135}$ While the danger of competitive harm through misallocation may not be great, it cannot simply be dismissed as trivial.

The critics' second fear is that the BOC's might use their local exchange monopolies to obstruct others in competitive sectors, with an eye to gaining for themselves a large enough market share to facilitate future monopoly profits. For instance, a local company might design its exchange services so as to be most compatible with its own information services or equipinent. ${ }^{136}$ It might also directly hinder competitors who seek necessary local connections. ${ }^{137}$ Because of the ease with which much of this behavior might be defended on grounds of "efficiency,"138 its prevention on a case-by-case basis might prove especially difficult. In a nutshell, this argument suggests that it is a mistake to let a bridge owner go into the railroad business, lest it use its power over the bridge to obstruct competing railroads. The argument is logically sound, but the question is one of balancing. Are the risks of such undetected conduct great enough to warrant prohibition?

Before we can answer this question (a task that this Article does not attempt), we must ask about the potential benefits of BOC entry. These benefits appear to be much stronger here than in the case of the CRS. First, there may be economies in having BOC's provide certain information services along with telecommunications. These economies include efficiencies in integrating equipment, avoiding facilities duplication, and increasing the convenience of consumers who would receive a broader range of telecommunications services from a single supplier. ${ }^{139}$ In fact, competitors of the BOC's point to these possible economies when they claim that it will be difficult for a regulator to catch anticompetitive abuses. Second, the ability to offer these services may help the regulated

135. See Western Electric, 592 F. Supp. at 854-55; T. Brennan, supra note 133, at 22; see also NTIA, supra note 52, at 75 (suggesting that cost accounting and allocation requirements to prevent cross-subsidization would be more efficient than requiring structural separation of services in regulated and unregulated markets); infra text accompanying notes 139-141 (discussing efficiencies that would result from allowing BOC's to offer a wider range of services).

136. See $A T \& T, 552$ F. Supp. at 188-91; T. Brennan, supra note 133, at 13-16, $39-40$ (arguing that opportunities for this form of discrimination exist even in the markets specifically opened to the BOC's by the Modification of Final Judgment, the settlement that ended the antitrust action against AT\&T in 1974).

137. The Justice Department's original case against AT\&T was based largely on allegations of such obstruction. See AT\&T, 524 F. Supp. at 1348-50, 1360-61; MacAvoy \& Robinson, supra note 57, at 14-16.

138. A company might claim, for instance, that its services are most compatible with its own equipment only because this is the cheapest way to construct the services, or that its delay in connecting competitors is due to technical difficulties. See T. Brennan, supra note 133, at 40.

139. See generally NTIA, supra note 52, at 77-82 (describing inefficiencies resulting from current restrictions on BOC operations); T. Brennan, supra note 133, at 24-25 (stating that economies of scope may justify allowing regulated firms to enter unregulated markets); Kahn, supra note 61 , at 9 (discussing the social costs of relying on several companies to provide different aspects of telephone service, rather than on one integrated telephone service company). 
BOC attract firms away from bypassing, thereby helping to protect residential customers from increased rates. ${ }^{140}$ Third, allowing the BOC's to enter means new competition in competitively structured industries. ${ }^{141}$ These benefits tend to neutralize the anticompetitive disadvantages of integration.

\section{Resolving Bottlenecks}

Having identified the anticompetitive dangers and economic benefits of bottlenecks in both the airline and telecommunications industries, our remaining task is to identify which institutions are best suited to resolving the problems posed. Should we deal with these potential anticompetitive problems through antitrust or a regulatory mechanism? Antitrust policy is administered primarily by courts, operating through rule and precedent. Courts find it difficult to reverse direction or to have a change of heart once a case is decided. Courts also have difficulty investigating underlying circumstances-particularly changes in circumstancesbecause they depend upon a record, produced through an adversarial process, for their information. In addition, courts find it difficult to balance factors tending $\mathrm{m}$ opposite directions, for they are uncomfortable in the absence of standards for weighing each factor in the balance.

The regulatory agency is more flexible. It has a staff that can conduct factual investigations. Because it has less need to consider the precedential value of what it does, it can more easily experinnent and make exceptions. Finally, perhaps because it can rely more easily upon its expertise to justify its decisions, it hesitates less to balance competing factors to reach a result. Regulation exacts a price, however, in terms of delayed decisions, expensive bureaucracy, diminished predictability, and imperfect replication of the free market.

These institutional considerations, combined with the foregoing substantive analysis, point in the following direction. The telecommunications "bottleneck" problem seems more amenable to regulatory control. BOC's could enter other lines of business provided an agency supervises their basic local-service pricing behavior, scrutinizing their conduct to ensure that they do not take unfair advantage of a local telecommunications monopoly to restrict or deny a competitor essential services. Regulatory supervision seems appropriate because there are both economic benefits and competitive risks to allowing entry; continued supervision may help to maximize the benefits while minimizing the risks.

The CRS bottleneck poses a set of practical questions concerning relief. Would the obvious stringent antitrust solution-divestiture-

140. See MacAvoy \& Robinson, supra note 60 , at 254.

141. See id. at 254-55; Brennan, supra note 133, at 25-26. 
prove too costly? Is it possible to require partial ownership by other airlines, effectively forcing existing owners to become joint venturers? Just how expensive, in terms of efficiency, would these solutions be? Would the only other alternative-some form of continued government supervision or regulation-prove still more costly?

To answer the practical questions and resolve the policy considerations would require considerably more detailed analysis than I have been able to provide. It would also require gathering facts to evaluate my rough empirical judgments. But if the main points I have raised are roughly correct, the present situation, institutionally speaking, seems ironic. Instead of using regulation to supervise BOC entry into new fields, we are using an antitrust court essentially to forbid it, at least in fields related to telephone service. ${ }^{142}$ Instead of searching for ways to change the structure of CRS ownership, we are regulating CRS conduct. Although CRS regulation may turn out to be necessary, our basic institutional instinct seems backward.

\section{CONCLUSION}

My purpose in this Article has not been to provide answers or to suggest policies. I concede that I have come close to suggesting that the differences between the superficially similar cases of airlines and telecommunications cast some doubt on the utility of what Part I calls the "classical theory." And from time to time, I have hinted that deregulation may be better done by Congress than by courts. But I have stayed away from arguing such controversial conclusions. Rather, $I$ have tried to analyze problems and to suggest that deregulation, like regulation, will raise a host of difficult analytic problems that traditional antitrust policy cannot resolve. I have, as Professor Handler asked, focused upon special risks the public faces in the newly deregulated world. I have found at least four such risks, which should alert us to four corresponding policy needs:

(1) the need for a strong antitrust policy to maintain competitive market structures;

(2) the need to avoid protecting competitors where doing so is inconsistent with promoting competition;

(3) the need to follow sound economic principles where reg-

142. See Western Electric, 592 F. Supp. at $867-68$ (denying BOC entry into interexchange markets); 627 F. Supp. 1090 (same case) (denying BOC entry into interexchange and information services markets); 1986-1 Trade Cas. (CCH) \ 66,987, at 62,060-62 (same case) (denying BOC entry into paging, mobile radio and voice storage and retrieval markets); $c f$. United States v. GTE Corp., 603 F. Supp. 730 (D.D.C. 1984) (approving consent decree allowing GTE to acquire Sprint, despite objections by Department of Justice under Clayton Act). 
ulation continues in other segments of the industry or in related industries; and

(4) the need to minimize the potential anticompetitive impact of residual monopoly power in newly deregulated industries.

These needs are, in a sense, old ones, but the deregulation of the airline and telecommunications industries increases the importance of our recognizing and satisfying them. 


\section{APPENDIX}

\section{TABLE 1}

Real Revenues and Fares Adjusted with the Consumer Price Index

\begin{tabular}{|c|c|c|c|c|}
\hline \multirow[b]{2}{*}{ Year } & \multicolumn{2}{|c|}{$\begin{array}{c}\text { Average fare per } \\
\text { Revenue Passenger Mile }\end{array}$} & \multirow{2}{*}{$\begin{array}{c}\text { Revenue } \\
\text { Passenger Miles } \\
\text { (Billions) }\end{array}$} & \multirow{2}{*}{ 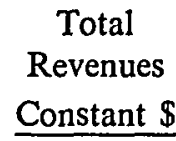 } \\
\hline & Current $\$$ & Constant \$ & & \\
\hline 1973 & .066 & .154 & 129.3 & 19.912 \\
\hline 1974 & .075 & .158 & 133.0 & 21.014 \\
\hline 1975 & .077 & .149 & 135.2 & 20.145 \\
\hline 1976 & .082 & .150 & 149.1 & 22.365 \\
\hline 1977 & .086 & 147 & 161.3 & 23.711 \\
\hline 1978 & .085 & 135 & 188.2 & 25.407 \\
\hline 1979 & .089 & 127 & 209.9 & 26.657 \\
\hline 1980 & .116 & . 146 & 201.3 & 29.390 \\
\hline 1981 & .131 & 150 & 199.9 & 29.985 \\
\hline 1982 & .123 & 132 & 212.0 & 27.984 \\
\hline 1983 & . 121 & .126 & 229.4 & 28.904 \\
\hline 1984 & .129 & 129 & 246.2 & 31.760 \\
\hline 1985 & .122 & 118 & 270.1 & 31.817 \\
\hline
\end{tabular}

Notes: a) Dollar Figures are adjusted to 1984 dollars using the Consumer Price Index.

b) Total revenue is in billions of 1984 dollars (and is equal to average fare per RPM multiplied by number of RPM).

Source: U.S. General Accounting Office, Deregulation: Increased Competition Is Making Airlines More Efficient and Responsive to Consumers, Appendices III, XXI, and XXII (November 6, 1985). 
TABLE 2

Passenger Savings If Airlines Fares Had Increased With The Rate of Inflation in the Consumer Price Index (1973 base)

\begin{tabular}{|c|c|c|c|}
\hline Year & $\begin{array}{l}\text { Savings in } 1973 \\
\text { passenger miles }\end{array}$ & $\begin{array}{l}\text { Savings on additional } \\
\text { passenger miles flown }\end{array}$ & Total \\
\hline 1974 & 0.517 & 0.015 & 0.532 \\
\hline 1975 & -0.647 & -0.030 & -0.677 \\
\hline 1976 & -0.517 & -0.079 & -0.596 \\
\hline 1977 & -0.905 & -0.224 & -1.129 \\
\hline 1978 & -2.457 & -1.119 & -3.576 \\
\hline 1979 & -3.491 & -2.176 & -5.667 \\
\hline 1980 & -1.034 & -0.576 & -1.610 \\
\hline 1981 & -0.517 & -0.282 & -0.799 \\
\hline 1982 & -2.845 & -1.819 & -4.664 \\
\hline 1983 & -3.620 & -2.803 & -6.423 \\
\hline 1984 & -3.233 & -2.923 & -6.156 \\
\hline 1985 & -4.655 & -5.069 & -9.724 \\
\hline Total & -23.404 & -17.085 & -40.489 \\
\hline
\end{tabular}

Notes: a) All amounts are billions of 1984 dollars, adjusted using the Consumer Price Index.

b) Column 1 gives the reduction in airline revenues (savings in passenger costs) to fly the same number of miles as flown in 1973; it is the difference between the inflation adjusted average fare per RPM in each year and the 1973 average fare, multiplied by the number of miles flown in 1973. In arithmetic terms, Column 1 equals $\left(P_{t}-P_{73}\right) \times Q_{73}$. c) Column 2 gives the additional reduction in airline revenues (savings in passenger costs) realized on additional miles flown; it is the difference between the inflation adjusted average fare per RPM in each year and the 1973 average fare, multiplied by the number of miles flown in each year in excess of total 1973 mileage. In arithmetic terms, Column 2 equals $\left(\mathrm{Q}_{\mathrm{t}}-\mathrm{Q}_{73}\right) \times\left(\mathrm{P}_{\mathrm{t}}-\mathrm{P}_{73}\right)$.

d) Column 3 is the sum of Columns 1 and 2.

Source: Calculated from data in Table 1. 
